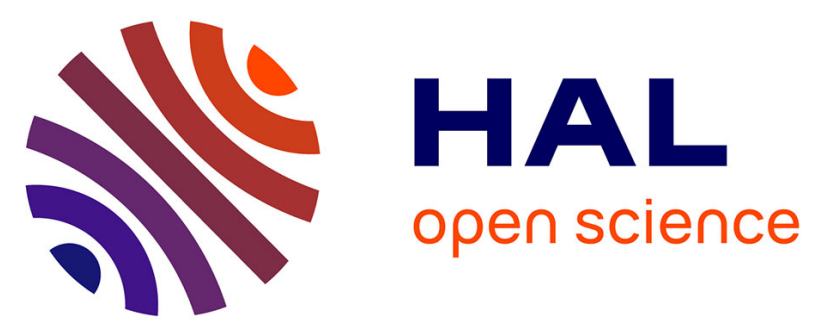

\title{
Lung development, regeneration and plasticity: From disease physiopathology to drug design using induced pluripotent stem cells
}

Engi Ahmed, Caroline Sansac, Said Assou, Delphine Gras, Aurélie Petit, Isabelle Vachier, Pascal Chanez, John de Vos, Arnaud Bourdin

\section{To cite this version:}

Engi Ahmed, Caroline Sansac, Said Assou, Delphine Gras, Aurélie Petit, et al.. Lung development, regeneration and plasticity: From disease physiopathology to drug design using induced pluripotent stem cells. Pharmacology and Therapeutics, 2018, 183, pp.58-77. 10.1016/j.pharmthera.2017.10.002 . hal-01743899

\section{HAL Id: hal-01743899 \\ https://hal.science/hal-01743899}

Submitted on 14 Jan 2020

HAL is a multi-disciplinary open access archive for the deposit and dissemination of scientific research documents, whether they are published or not. The documents may come from teaching and research institutions in France or abroad, or from public or private research centers.
L'archive ouverte pluridisciplinaire HAL, est destinée au dépôt et à la diffusion de documents scientifiques de niveau recherche, publiés ou non, émanant des établissements d'enseignement et de recherche français ou étrangers, des laboratoires publics ou privés. 


\title{
Lung development, regeneration and plasticity: From disease physiopathology to drug design using induced pluripotent stem cells
}

\author{
Engi Ahmed ${ }^{\mathrm{a}, \mathrm{b}, \mathrm{c}, \mathrm{d}, 1}$, Caroline Sansac ${ }^{\mathrm{b}, 1}$, Said Assou ${ }^{\mathrm{b}, \mathrm{c}, \mathrm{d}}$, Delphine Gras ${ }^{\mathrm{e}}$, Aurélie Petit ${ }^{\mathrm{f}}$, \\ Isabelle Vachier ${ }^{\mathrm{f}}$, Pascal Chanez ${ }^{\mathrm{e}}$, John De Vos ${ }^{\mathrm{b}, \mathrm{c}, \mathrm{d}, \mathrm{g}, *, 2}$, Arnaud Bourdin ${ }^{\mathrm{a}, \mathrm{d}, \mathrm{f}, * *, 2}$ \\ a Department of Respiratory Diseases, Hôpital Arnaud de Villeneuve, Montpellier F34000, France \\ ${ }^{\mathrm{b}}$ CHU Montpellier, Institute for Regenerative Medicine and Biotherapy, Hôpital Saint-Eloi, Montpellier F34000, France \\ ' INSERM, U1183, Montpellier F34000, France \\ ' Université de MONTPELLIER, UFR de Médecine, Montpellier F34000, France \\ e Dept of Respiratory Diseases APHM, INSERM CNRS U 1067, UMR7333, Aix-Marseille University, Marseille, France \\ ${ }^{\mathrm{f}}$ INSERM, U1046, PhyMedExp, Montpellier F34000, France \\ ${ }^{g}$ CHU Montpellier, Unit for Cellular Therapy, Hospital Saint-Eloi, Montpellier F 34000, France
}

Keywords:

Stem cells

Induced pluripotent stem cells

Airways

Chronic airway diseases

\begin{abstract}
A B S T R A C T
Lungs have a complex structure composed of different cell types that form approximately 17 million airway branches of gas-delivering bronchioles connected to 500 million gas-exchanging alveoli. Airways and alveoli are lined by epithelial cells that display a low rate of turnover at steady-state, but can regenerate the epithelium in response to injuries. Here, we review the key points of lung development, homeostasis and epithelial cell plasticity in response to injury and disease, because this knowledge is required to develop new lung disease treatments. Of note, canonical signaling pathways that are essential for proper lung development during embryogenesis are also involved in the pathophysiology of most chronic airway diseases. Moreover, the perfect control of these interconnected pathways is needed for the successful differentiation of induced pluripotent stem cells (iPSC) into lung cells. Indeed, differentiation of iPSC into airway epithelium and alveoli is based on the use of biomimetics of normal embryonic and fetal lung development. In vitro iPSC-based models of lung diseases can help us to better understand the impaired lung repair capacity and to identify new therapeutic targets and new approaches, such as lung cell therapy.
\end{abstract}

\section{Introduction}

Chronic airway diseases are among the most common medical conditions worldwide and include, but are not restricted to, cystic fibrosis (CF), asthma and chronic obstructive pulmonary disease (COPD). The global burden of COPD is still increasing, and this disease is becoming the 3rd leading cause of death and the 5th cause of disability worldwide (Lozano et al., 2012). In westernized countries, COPD affects between $5 \%$ and $10 \%$ of the general population (Reddel et al., 2015;
Vogelmeier et al., 2017). Asthma prevalence also is increasing, but with large regional differences. In westernized countries, it may affect $10 \%$ of the general population (Reddel et al., 2015). Therefore, the direct and indirect costs attributed to asthma and COPD management might be among the most important causes of the health economic burden.

COPD is a chronic disease punctuated by exacerbations with progressive worsening and accumulation of comorbidities. Unfortunately, the currently available treatments cannot interfere with COPD natural history and they remain mostly symptomatic. Existing therapies for

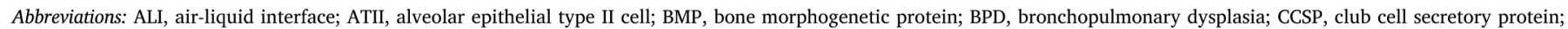

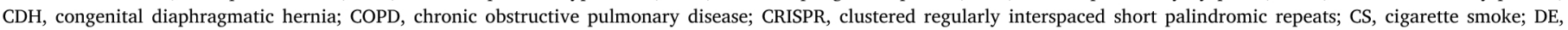

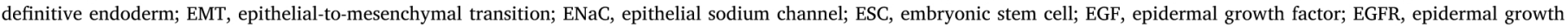

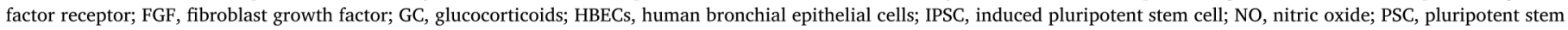

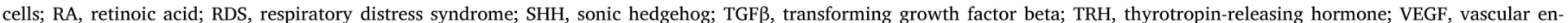
dothelial growth factor

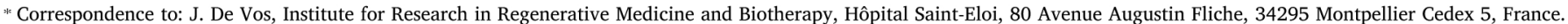

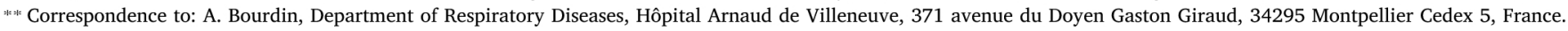

E-mail addresses: john.devos@inserm.fr (J. De Vos), a-bourdin@chu-montpellier.fr (A. Bourdin).

1 These authors contributed equally to this work.

${ }^{2}$ Co-senior author. 
COPD modestly improve airflow and symptoms, but no currently available treatment significantly slows down disease progression or reverses the structural changes that compromise lung function. Disabling breath shortness can affect the occupational and daily living activities. Moreover, COPD exacerbations might represent life-threatening episodes that frequently lead to hospital admission and readmission (Müllerova et al., 2015). Similarly, asthma is a concern for children and adults and could interfere with their education and occupational attendance.

In the last ten years, the COPD pathophysiology paradigm shifted from inflammation towards impaired epithelial homeostasis. Indeed, the key role of the airway epithelium is now better established in asthma and COPD (Gras, Chanez, Vachier, Petit, \& Bourdin, 2013; Holgate, 2008; Lambrecht \& Hammad, 2012). In COPD, air pollutants, such as occupational noxious agents or cigarette smoke (CS), disrupt the epithelial homeostasis, thus hindering the harmonious repair and favoring metaplasia and goblet cell hyperplasia (Araya et al., 2007; Saetta et al., 2000). In asthma, exaggerated airway inflammation is now recognized as part of the inappropriate epithelial-mesenchymal crosstalk through Th2 alarmin release (Holtzman, Byers, Alexander-Brett, \& Wang, 2014).

Progress in understanding chronic airway diseases relies on relevant in vitro models. Induced Pluripotent Stem Cells (iPSC) provide a radically new approach to tackle lung disease research and treatment. Cell reprogramming allows the dedifferentiation of specialized adult cells into iPSC that can then be differentiated into any cell type, including the various airway epithelial cells (Huang et al., 2015; Mou et al., 2012; Wong et al., 2015). Therefore, iPSC, ideally obtained from selected patients, could be used to screen new drugs and to test their toxicities, by in vitro modeling of lung development and diseases. Moreover, by providing an unlimited source of progenitor and specialized lung cells, iPSC offer the unique possibility to regenerate damaged lungs by cell therapy (Ghaedi \& Niklason, 2016). In vitro recapitulation of airway epithelial development and maintenance using iPSC relies on the pharmacological control of several molecular checkpoints that mimic embryological and fetal processes. These interconnected mechanisms are highly complex because the airway epithelium includes many different cell types.

In this review, first we summarize the current knowledge on lung development and plasticity, and then develop the idea that each of these checkpoints must be understood for iPSC-derived lung modeling and as valuable pharmacological targets.

\section{Lung development and regeneration}

\subsection{Airway development: different stages and molecular regulations}

Airway development is a highly regulated process that can be divided in five steps: (i) embryonic, (ii) pseudoglandular, (iii) canalicular, (iv) saccular, and (v) alveolar stage (Chao, El Agha, Tiozzo, Minoo, \& Bellusci, 2015; Hislop, 2002) (Fig. 1A). The embryonic stage starts during gastrulation, when the formation of the primitive streak is followed by the appearance of the definitive endoderm (DE) and the protrusion of the lung bud from its ventral side. The first division of the lung bud gives rise to the future trachea and primary bronchi, and the subsequent 8-13 divisions produce the bronchial tree. The pseudoglandular stage is characterized by the generation of bronchi during $3-10$ generations. It is followed by the canalicular stage in which the terminal and respiratory bronchioles are formed. At the end of this stage, at around month 6 of gestation in humans, a complex arborized network of airways is established, as well as the bases of the blood gas barrier through the thinning of the respiratory bronchiolar epithelium. During the saccular stage, fully functional lungs are produced through the expansion of the distal respiratory bronchioles and the formation of the primitive alveoli. Finally, particularly in humans, alveoli will continue to mature post-natally by increasing their surface during the alveolar stage. Five main epithelial cell types, characterized by specific markers, support the airway functions: goblet cells (MUC5A$\mathrm{C}+\mathrm{TFF} 3+$ ), ciliated cells ( $\beta$ TUBIV + FOXJ1 + DNAI2 +), basal cells $($ KRT5/14 + TP63 + CD151 +), neuroendocrine cells (CGRP + Chromogranin A +) and club cells (CCSP +) (Gras et al., 2013) (Fig. 1B). Alveoli are composed of alveolar type I epithelial cells, which are critical for gas exchanges, and alveolar type II (ATII) cells, which produce surfactant that is required for alveolar integrity. Ultimately, approximately 17 million airway branches of gas-delivering bronchioles are generated that are connected to 500 million gas-exchanging alveoli (Ochs et al., 2004; Peng \& Morrisey, 2013).

Lung development is finely controlled by several transcription factors and growth factors. Deregulations in their temporal expression result in defects in lung development or homeostasis. In-depth knowledge of this sequence of events is necessary also to understand lung disease development and to generate airway cells in vitro by differentiating iPSC (see below). DE formation is marked by the strong expression of the transcription factors SOX17 and FOXA2. DE is then subdivided in foregut, midgut and hindgut along the anteriorposterior axis. The foregut is characterized by the expression of FOXA2 and SOX2. Then, the transcription factor NKX2.1 marks the ventral part of the anterior foregut from which the lung bud will stem. Later, during airway branching, proximal endoderm progenitors express SOX2 and distal endoderm progenitors express SOX 9 and the transcriptional regulator ID2 (Herriges \& Morrisey, 2014). HOX genes regulate the three-dimensional lung development. Early airway specification and development requires both WNT and bone morphogenetic protein (BMP) signaling. FGFs, mainly FGF10, are among the main actors of induction of airway branching and budding and also of alveolarization. Conversely, SHH suppresses FGF10 signaling and branching. FGF2 and FGF7 contribute to distal airway differentiation, promoting ATII cell differentiation and production of surfactant protein C (Warburton et al., 2003). Epidermal and insulinlike growth factors are involved in airway proliferation and RA increases the total number of alveoli (Massaro \& Massaro, 1996). RA also induces FG10 production. Vascular endothelial growth factor (VEGF) also is involved in alveolarization through distal airway vascularization. The WNT pathway also controls the homeostasis of distal stem cells (bronchoalveolar stem cells) in the mouse. Specifically, in Gata6 knock-out mice, the WNT pathway is upregulated, leading to bronchoalveolar stem cell expansion (Zhang et al., 2008). Furthermore, WNT/beta-catenin signaling regulates the airway epithelium proximal-distal differentiation and also promotes upregulation of BMP4 and N-myc, two effector molecules involved in the maintenance of the airway proximal-distal pattern (Shu et al., 2005).

\subsection{Airway regeneration}

The airway walls represent an efficient physical barrier at the interface with the external environment and airway epithelial cells are the first lung cells exposed to exogenous injuries caused by microorganisms, airborne irritants and allergens. In conditions of homeostasis, airway progenitor cells are quiescent, but have the capacity to regenerate the epithelium in response to injuries, such as infectious agents or tobacco smoke (Beers \& Morrisey, 2011). In humans, the spontaneous turnover of this epithelium cannot be easily assessed in vivo, and most of the current knowledge has been extrapolated from animal models or using in vitro reconstituted epithelium from human cell lines, or primary human bronchial epithelial cells (HBECs) grown in a two-dimensional air-liquid interface (ALI) culture system. In steady state and epithelial repair conditions, basal cells can self-renew and differentiate during normal homeostatic turnover and after injury (Rock et al., 2009) (Fig. 1C). Similarly, club cells can self-renew and differentiate into ciliated cells and goblet cells (Kotton \& Morrisey, 2014) (Fig. 1D) and alveolar epithelial type I (ATI) cells derived from selfrenewing ATII precursors (Fig. 1E). Other stem cell types, such as 


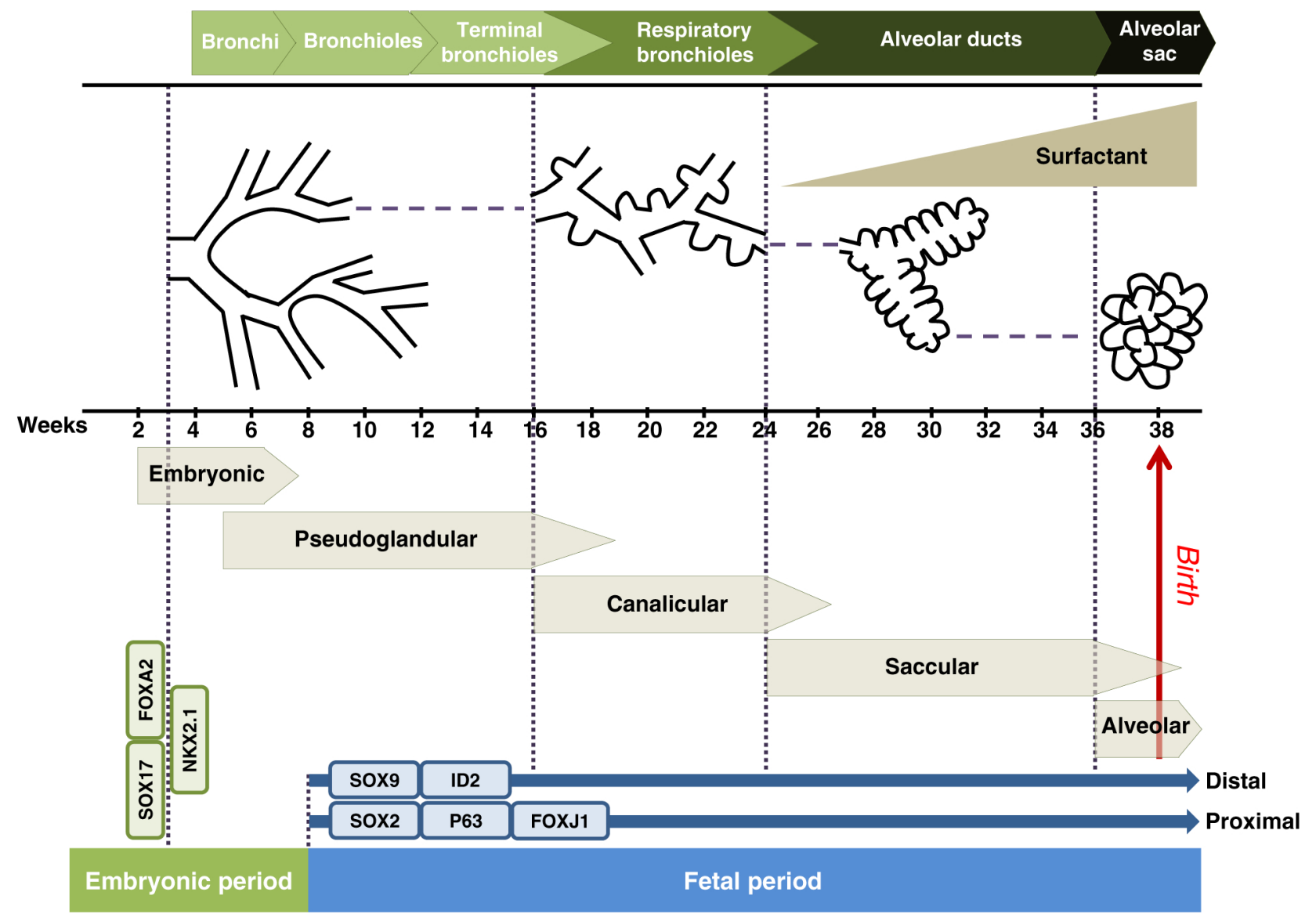

Fig. 1. Overview of human lung structural organization and development stages.

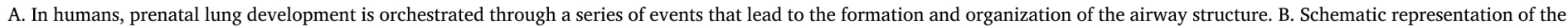

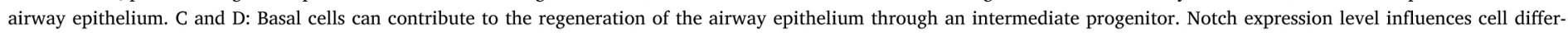

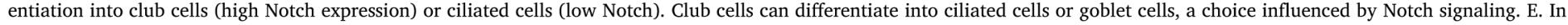

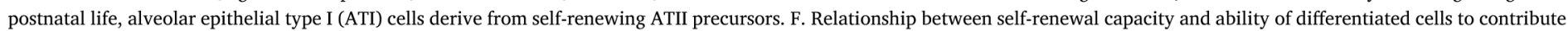

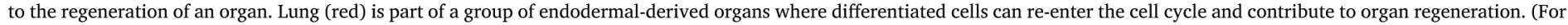
interpretation of the references to color in this figure legend, the reader is referred to the web version of this article.)

Panel A was modified from http://www.embryology.ch/. Panel F was adapted from Kotton \& Morrisey (2014).

neuro-epithelial bodies, cells situated at the bronchoalveolar duct junctions, circulating bone marrow cells and ATII cells, are less well characterized in humans (Donne, Lechner, \& Rock, 2015; Kajstura et al., 2011; Paisley, Bevan, Choy, \& Gross, 2014; Wong et al., 2009). For instance, another study suggested that ciliated airway epithelial cells may also trans-differentiate to rescue airway epithelium plasticity (Tata et al., 2013).

Differently from organs that rely on well-defined undifferentiated stem cell population(s), lung homeostasis regulation is more similar to what observed in endodermal-derived organs, such as liver and pancreas, where differentiated cells can re-enter the cell cycle and contribute to organ regeneration (Fig. 1F) (Kotton \& Morrisey, 2014). At a glance, evidences for respective contribution and alternative commitment of differentiation (acquisition of differentiation phenotype such as cilia), dedifferentiation (loss of differentiation features) and transdifferentiation (from one to another differentiated cell type) pathways in humans are extremely sparse.

\subsection{Aberrant airway regeneration in chronic airway diseases}

Aberrant airway epithelium regeneration (Holgate, 2007) is observed in chronic airway diseases, such as asthma and COPD and is summarized in Table 1 (Gohy et al., 2015). is a major cause of death and morbidity worldwide. Like in other chronic obstructive airway diseases, lesions in COPD initiate and progress predominantly at the "silent" small airway level. COPD silent progression explains why diagnosis is delayed and often occurs at late stages. This might also explain why the available pharmacological treatments cannot stop the natural course of COPD, because anatomical lesions are not reversible in patients with end-stage disease (Hogg et al., 2004; McDonough et al., 2011). The imbalance between inappropriate repair of the airway epithelium in response to chronic injury (for instance, CS, exogenous agents) could play a role in COPD progression, as suggested by the presence of peribronchiolar fibrosis, squamous metaplasia, reduced number of club cell secretory protein (CCSP)-expressing cells and hyperplasia of mucus-secreting epithelial cells associated with an increased ratio of goblet to ciliated cells (Araya et al., 2007; Bourdin et al., 2010; Cosio et al., 1978; Gamez et al., 2015; Hogg et al., 2004; Innes et al., 2006; Peters et al., 1993; Saetta et al., 2000; Shaykhiev \& Crystal, 2014). Infiltration of inflammatory cells within the different airway wall compartments is a hallmark of exacerbation episodes, usually triggered by viruses and/or bacteria, although different inflammatory endotypes are now recognized (Bafadhel et al., 2012; Pascoe, Locantore, Dransfield, Barnes, \& Pavord, 2015). The epithelial cell regulation of these different immune responses is currently under investigation (Byers et al., 2013; von Moltke, Ji, Liang, \& Locksley, 2016). 

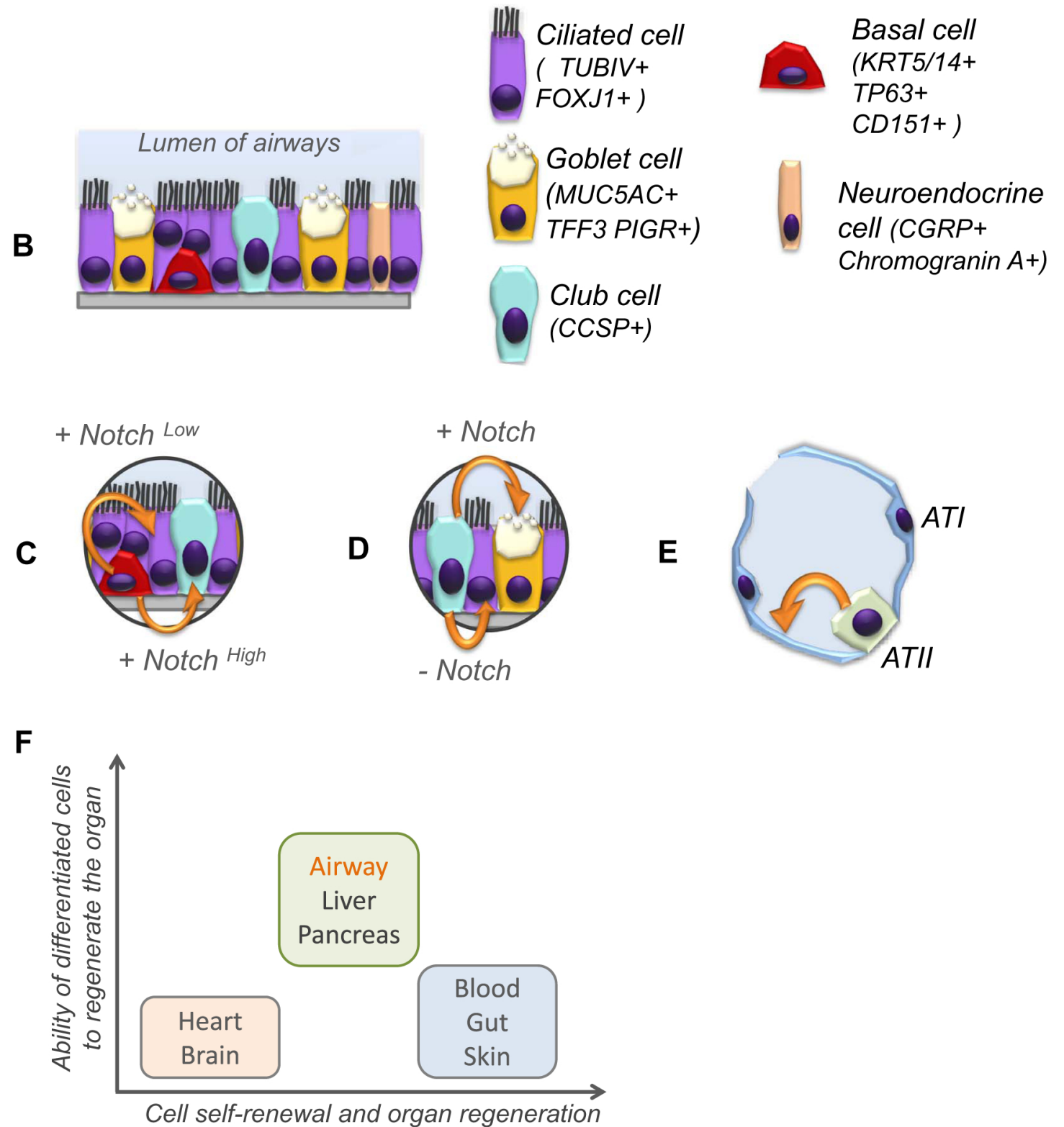

Fig. 1. (continued)

pathways involved in lung development and repair are deregulated in COPD. Recent studies, including genome-wide association analyses and whole-genome expression profiling, suggest that some critical molecular regulators of lung development and repair are altered in patients with COPD (Selman, Pardo, \& Kaminski, 2008) and this directly contributes to COPD development and progression (Shi, Chen, \& Cardoso, 2009). These pathways include particularly the WNT, SHH and Notch signaling cascades (Aoyagi-Ikeda et al., 2011; Königshoff et al., 2009; Kugler, Joyner, Loomis, \& Munger, 2015). Exposure to CS affects wound repair in injured bronchial epithelial cells (Allen-Gipson et al., 2013) and also deregulates DNA methylation in small airways of patients with COPD. This alteration is associated with changes in the expression of genes required for airway remodeling and regeneration (Vucic et al., 2014). Moreover, in a wound closure assay using HBECs, the severity of airflow obstruction and emphysema was associated with slower epithelial wound repair (Perotin et al., 2014).

Finally, it has been hypothesized that COPD, but also asthma, could be caused by incomplete lung growth during fetal and early post-natal life (Bush, 2008; Lange et al., 2015). These pediatric roots could explain why the identification of the ideal therapeutic window for initiating effective COPD treatment is challenging (Martinez, 2016; McGeachie et al., 2016). Therefore, biomarkers to predict the risk of developing COPD and asthma are needed. The circulating level of club cell secretory protein (CCSP) in early childhood is a potential candidate biomarker to predict incomplete lung growth (Guerra et al., 2015) and accelerated lung function decline in adulthood (Vestbo et al., 2011).

Below, we discuss the main evidences supporting the idea of aberrant airway regeneration in COPD, by focusing on four aspects: reepithelialization, EMT, cellular composition of the bronchial epithelium and cell senescence.

2.3.1.3. Defective mechanisms of re-epithelialization during wound healing. In COPD, wound repair is defective, particularly reepithelialization (Heijink, Noordhoek, Timens, van Oosterhout \& Postma, 2014; Perotin et al., 2014; Shaykhiev et al., 2011). Recovering the polarity of epithelial cells is a major outcome at the end of wound repair. Indeed, loss of contact inhibition and apical polarity is initially required for epithelial cell migration in the wound, but must be finely regulated and stopped. The involved mechanisms are not fully understood. At the end of the repair process, epithelial cell proliferation is inhibited by MMP-2 (Lechapt-Zalcman et al., 2006). Long-term or multiple stimulations of progenitor cells can lead to aberrant cell proliferation and consequently to metaplasia and cancer. 
Table 1

Cellular and histological features of aberrant epithelial repair in chronic airways diseases (COPD, asthma).

\begin{tabular}{|c|c|c|}
\hline $\begin{array}{l}\text { Disease/ } \\
\text { epithelial } \\
\text { modifications }\end{array}$ & COPD & Asthma \\
\hline $\begin{array}{l}\text { Cell } \\
\text { modifications }\end{array}$ & $\begin{array}{l}\Delta \text { Goblet cells } \\
\text { (hyperplasia \& hypertrophy) } \\
\text { A Basal cells } \\
\text { (hyperplasia \& metaplasia) } \\
\nabla \text { Ciliated cells (shortened cilia) } \\
\nabla \text { Club cells } \\
\nabla \text { Barrier function \& } \\
\nabla \text { Epithelial permeability: } \\
\nabla \text { Apical polarity } \\
\nabla \text { Transepithelial electrical } \\
\text { resistance } \\
\Delta \text { Cell senescence }\end{array}$ & $\begin{array}{l}\Delta \text { Goblet cells } \\
\text { (transdifferentiation of } \\
\text { club and ciliated cells) } \\
\Delta \text { Basal cells } \\
\nabla \text { Ciliated cells }\end{array}$ \\
\hline $\begin{array}{l}\text { Histological } \\
\text { modifications }\end{array}$ & $\begin{array}{l}\text { Squamous metaplasia of } \\
\text { goblet cells (correlate to tobacco } \\
\text { smoke exposure) and basal cells } \\
\text { Peribronchiolar fibrosis } \\
\text { A EMT: } \\
\text { Tight junctions, adherent } \\
\text { junctions (E-cadherin), apical } \\
\text { junctions } \\
\nabla \text { Proximal-distal pattern }\end{array}$ & $\begin{array}{l}\text { Basement } \\
\text { membrane thickening } \\
\text { Goblet cell } \\
\text { metaplasia } \\
\text { Epithelium loss } \\
\text { EMT (suggested, } \\
\text { but not confirmed) }\end{array}$ \\
\hline
\end{tabular}

A : Increase $\nabla$ : Loss. EMT, epithelial-mesenchymal transition.

Epithelial cell hyperplasia near injury areas could be triggered by mechanotransduction (Desai, Chapman, \& Waters, 2008) and excessive epithelial growth factor (EGF) signaling (Stoscheck, Nanney, \& King, 1992). Unfortunately, EGF receptor (EGFR) inhibition was not successful for COPD management (Woodruff et al., 2010). Epithelial cell migration is also regulated by the tumor suppressor p21 and its absence leads to loss of cell-cell contacts (Li et al., 2014).

CS and COPD are associated with increased airway epithelial permeability, as indicated by transepithelial resistance measurement. CS impairs the airway epithelial barrier function through loss of E-cadherin and cell-cell contact recovery (Heijink et al., 2012; Heijink, Nawijn, \& Hackett, 2014; Oldenburger et al., 2014; Shaykhiev et al., 2011; Somborac-Bacura et al., 2013). A recent transcriptome analysis revealed the global down-regulation of apical junctional complex genes in the airway epithelium of healthy smokers and patients with COPD compared with non-smokers (Shaykhiev et al., 2011).

2.3.1.4. Epithelial-to-mesenchymal transition in COPD. Epithelial to mesenchymal transition (EMT) is a key mechanism in wound healing. EMT is characterized by progressive loss of epithelial markers, gain of migratory and invasive features and also of a secretory phenotype with production of extracellular matrix (ECM) components (Kalluri \& Weinberg, 2009). EMT in epithelial cells allows the repair and restoration of the injured epithelium integrity. Aberrant cell phenotypes could be related to the loss of EMT inhibition in the airways and its pathological persistence (Sohal, Ward, \& Walters, 2014). Most of our knowledge on EMT comes from other epithelial cell diseases, such as idiopathic pulmonary fibrosis (IPF) and cancer. One important EMT feature is the ability of migration that is enhanced through production of Matrix Metallo-Proteases (MMP) by migrating cells. MMPs promote migration by ECM degradation (Lagente et al., 2005; Puchelle, Zahm, Tournier, \& Coraux, 2006).

EMT has been documented in COPD airways (Sohal et al., 2010) by immunohistochemistry analysis and also using HBECs in ALI culture models (Mahmood et al., 2015; Nowrin, Sohal, Peterson, Patel, \& Walters, 2014; Sohal et al., 2014; Sohal, Mahmood, \& Walters, 2014; Sohal \& Walters, 2013). EMT occurs both in large and small airways (Mahmood et al., 2015) and is a potential mechanism that contributes to small airway fibrosis, the main mechanism of physiological airway dysfunction in COPD.

Deregulated production and activation of EMT mediators by altered epithelial cells will lead to an imbalance in ECM turn-over and induce lung parenchyma degradation and ECM deposition in bronchi and bronchioles in COPD, leading to peribronchial fibrosis (Fujii et al., 2012). Another indirect evidence of EMT in COPD is the presence of gaps within the reticular basement membrane. In these gaps and in epithelial cells close to the membrane, expression of the fibroblast markers S1004A, vimentin and MMP9 is increased (Sohal et al., 2010, 2011). Different factors can drive EMT in airways of smokers and patients with COPD. CS and nicotine promote EMT in epithelial cells of patients with COPD and of smokers through abnormal activation of the $\beta$-catenin/WNT pathway (Heijink et al., 2013; Zou, Zou, Zhao, Li, \& Ran, 2013). Câmara and Jarai (2010) showed that inflammatory mediators produced by the airway epithelium can induce EMT through the canonical transforming growth factor beta (TGF $\beta$ )/SMAD pathway (Zhang et al., 2009). Furthermore, they demonstrated that EMT is driven by TGF- $\beta$ signaling/SMAD in an inflammatory context. In an in vitro model (HBECs in ALI culture), TGF- $\beta 1$ inhibition prevents vimentin induction and fibronectin release. In COPD, the airway epithelium displays EMT features that correlate with peribronchial fibrosis and airflow limitation and that are partly caused by TGF- $\beta 1$-driven epithelial reprogramming (Gohy et al., 2015). In addition, TNF- $\alpha$ and IL-1, produced by the epithelium of patients with COPD, can also contribute to EMT (Sutherland \& Martin, 2003).

Wang, Wang, Zhang, Zhang, and Xiao (2013) were the first to evaluate the role of the urokinase plasminogen activator receptor (uPAR) signaling pathway in CS-driven EMT of COPD epithelium. When urokinase plasminogen activator (u-PA) binds to u-PAR, plasminogen is activated to form plasmin. Plasmin can then induce EMT through PI3K/ AKT activation. This mechanism has been described also in cancer and is disrupted in IPF.

\subsubsection{Changes in COPD epithelium}

2.3.1.5.1. Basal cells. In COPD, basal cells undergo metaplasia and hyperplasia. These changes are controlled by different signaling pathways, mainly EGFR and Notch signaling. Changes in basal cell behavior are mainly driven by CS (Hackett et al., 2011; Shaykhiev \& Crystal, 2014). Disruption of Notch-3/Jagged signaling results in basal cell expansion and altered pseudostratification (Mori et al., 2015). Paradoxically, although basal cell number is increased in the airway epithelium, regeneration is decreased. Indeed, in COPD, basal cells are hyperplastic, but their capacity to regenerate the airway epithelium in vitro is reduced (Staudt et al., 2014). Epigenetic modifications induced by CS also have been observed in basal cells of patients with COPD and in smokers (Vucic et al., 2014).

2.3.1.5.2. Club cells. Club cells play a protective role in COPD (Randell, 2006; Rawlins et al., 2009) and may contribute to epithelial regeneration and repair after injury, at least in mice (Perl, Riethmacher, \& Whitsett, 2011) (Fig. 1D). In mice that lack CCSP, exposure to CS leads to the development of COPD-like lung lesions that can be rescued by exogenous CCSP supplementation (Laucho-Contreras et al., 2015, p. 16). Therefore, although basal cells represent a key target of CS (Crystal, 2014), club cells should not be overlooked (Bourdin et al., 2010; Gamez et al., 2015; Knabe, Fort, Chanez, \& Bourdin, 2015; Lumsden, McLean, \& Lamb, 1984).

\subsubsection{Cell senescence: a COPD hallmark}

2.3.1.6.1. Senescence: accelerated ageing2.3.1.6.1.1. Normal ageing

Ageing is associated with changes in the lung that lead to a decrease in its function. Alterations in the structure and function in the small airways are well recognized in chronic lung diseases. Small airway epithelial cells form a selectively permeable layer that has many functions, such as providing a mechanical barrier against exogenous agents from the environment, immunological defense, and repair of airway injuries (Crystal, Randell, Engelhardt, Voynow, \& Sunday, 2008). 
Respiratory disorders, such as asthma, COPD and CF, involve inflammation, obstruction and epithelial cell injury of the small airways. The subsequent regeneration and repair of this epithelium are vital for maintaining the function and integrity of the small airways. In healthy adults, the small airway epithelium integrity is maintained by a fine balance between cell proliferation and cell death (Beers \& Morrisey, 2011). Alveolar enlargement is the best characterized lung change with age (Verbeken et al., 1992) and has been often seen in lung of elderly patients at autopsy. Development of non-invasive imaging techniques, such as micro-CT and CT, has allowed the study of lung ageing (Bommart et al., 2014, 2015).2.3.1.6.1.2. Senescence: a COPD hallmark

Senescence is one of the physiopathological hallmarks of COPD. In rodent models of COPD or exposure to tobacco (Tsuji, Aoshiba, \& Nagai, 2006), it has been clearly shown that senescence affects lung structural and inflammatory cells, fibroblasts and progenitors, thus hindering repair and regeneration. In humans, signs of cellular senescence have been detected in blood (Savale et al., 2009), reflecting a systemic process, but also in alveolar epithelium (by immunohistochemistry) and in the vascular compartment of COPD patients with pulmonary artery hypertension (Amsellem et al., 2011). Several hypotheses have been proposed to explain cell senescence. It could be caused by a defect or disruption of the niche of adult stem cells/progenitors or loss of progenitor function due to replicative limitation or Reactive Oxygen Species (ROS)-induced alterations (Boyer et al., 2015). Although cellular senescence might be considered at first as a pejorative process that involves premature ageing and loss of the organ function, it could also be a protective mechanism to avoid cancer in a hostile environment. In agreement, autophagy is significantly deregulated in cells from patients with COPD (Chen et al., 2008). In normal lung, autophagy contributes to maintaining tissue homeostasis (i.e., the balance between production, degradation and recycling of organelles and proteins) and helps tissue adaptation. Conversely, in COPD lung, chronic autophagy deficiency promotes tissue senescence and insufficient repair (Ryter, Lee, \& Choi, 2010; Fujii et al., 2012).

\subsubsection{Asthma}

2.3.2.1. Cellular and structural abnormalities in asthma. Asthma is characterized by remodeling of the epithelial mesenchymal trophic unit (EMTU) (Holgate, 2008). An illustration of the altered EMTU function in asthma is the increase of the thickness of the basement membrane in association with epithelial cell shedding (Bourdin et al., 2007, 2004), including reduced expression of the adherens junction protein E-cadherin. Epithelium denudation is also observed. In biopsies from subjects with asthma, areas of epithelial damage are frequently observed and show strong EGFR immunostaining (Puddicombe et al., 2000). Small focal areas with non-ciliated cells can also be detected (Lundgren, Söderberg, Hörstedt, \& Stenling, 1988).

Goblet cell hyperplasia also has been described in asthma (Ordoñez et al., 2001). EGFR plays a major role in the regulation of mucus production. In asthma, EGFR signaling is increased in the airway epithelium (Polosa et al., 2002; Puddicombe et al., 2000; Takeyama, Fahy, \& Nadel, 2001). EGF is normally secreted at the basolateral side of the epithelium and does not interact with EGFR on the apical side because of the presence of epithelial junctions, such as adherens and tight junctions (Puddicombe et al., 2000). In people with asthma, IL-13 can induce EGF synthesis and release from the airway epithelium. IL-13 can also promote TGF-alpha release from epithelial cells that activate, in a paracrine manner, EGFR signaling in the epithelium to induce mucin production, goblet cell metaplasia (Habibovic et al., 2016; Takeyama et al., 2001) and proliferation of epithelial cells (Booth, Adler, Bonner, Tournier, \& Martin, 2001). SPDEF, P2YR, NOTCH, NKx2.1 and the DUOX/TACE/EGFR amplifying loop are known pathways involved in this process (Fahy \& Dickey, 2010; Maeda et al., 2011; Park et al., 2007; Shaykhiev et al., 2013).

Finally, the epithelium in airway sections and in vitro ALI cultures of epithelial cells from patients with asthma shows lower levels of differentiation with elevated numbers of basal cells that express cytokeratin-5, increased phosphorylation of p38 mitogen-activated protein kinase, (Hackett et al., 2011).

\subsubsection{Abnormal bronchial airway repair in asthma}

2.3.2.2.1. Disruption of epithelial cell repair in asthma. In vitro, HBECs from asthmatic children show a significantly longer repair time compared with cells from healthy donors, suggesting that epithelial cell repair is altered by asthma (Lundgren et al., 1988; Stevens, Kicic, Sutanto, Knight, \& Stick, 2008).

2.3.2.2.2. Epithelial-to-mesenchymal transition. It has been suggested that EMT contributes to the aberrant regeneration of the airway epithelium in asthma. In monolayer cultures incubated with TGF $\beta$, HBECs from asthmatic patients are more likely to undergo EMT than cells from controls (Hackett et al., 2009). Upon chronic intranasal exposure to house dust mite in a Th2 mice model of asthma, epithelial cells in large airways show EMT features, as suggested by the expression of mesenchymal markers (e.g., Snail), TGF $\beta$ upregulation and loss of E cadherin expression (Johnson, Roos, Berg, Nord, \& Fuxe, 2011).

2.3.2.2.3. Defect in the airway ability to restore epithelial junctions and re-epithelialization. Tight junctions are required for epithelial cell cohesion. Impaired epithelial permeability has been reported in asthma (Xiao et al., 2011). Disruption of the epithelium barrier may facilitate the entry of allergens and other offending agents in the airway tissue, leading to immune response activation by dendritic cells and, consequently, to a vicious circle of damage and immune response (Heijink, Nawijn \& Hackett, 2014). However, it is difficult to determine whether loss of epithelial junctions in asthma is the cause or the effect of allergic sensitization.

Impaired epithelial permeability could be the consequence of EGFRmediated EMT (Heijink et al., 2012; Heijink, Postma, Noordhoek, Broekema, \& Kapus, 2010; Heijink, van Oosterhout, \& Kapus, 2010) or the effect of T2-signature molecules, such as IL-4 and IL-13 (Ahdieh, Vandenbos, \& Youakim, 2001). A defect in caveolin-1, a known stabilizer of adherens junctions, also has been evoked because its membrane expression is significantly lower in airway epithelial cells from patients with asthma than from healthy controls. This reduced expression is maintained also in ALI-cultured HBECs. Interestingly, decreased caveolin-1 expression is accompanied by loss of junctional E-cadherin and $\beta$-catenin expression, disrupted epithelial barrier function and increased levels of the epithelial cytokine thymic stromal lymphopoietin (Hackett et al., 2013).

\section{Lung developmental pharmacology}

\subsection{Signaling pathways involved in airway epithelium plasticity}

The heterogeneous airway epithelium phenotype is regulated at different levels and this topic has been reviewed before (Gras et al., 2013). The core cell signaling pathways, such as WNT, SHH, Notch and BMP, must be modulated to influence in vitro (or in vivo) the differentiation toward a specific lung cell type. This modulation might require precise fine-tuning because trans-differentiation could be affected by the local microenvironment. The key data on the signaling pathways involved in airway epithelium plasticity are summarized in Table 2. These signaling pathways represent obvious pharmacological targets to influence airway epithelial plasticity. Such strategy was successful in a rodent model in which club cells could be directly converted into ciliated cells by blocking the Notch pathway (Lafkas et al., 2015).

\subsection{Drugs that affect airway development}

\subsubsection{Teratogenicity}

Each airway development stage (Fig. 1A) can be affected. The 


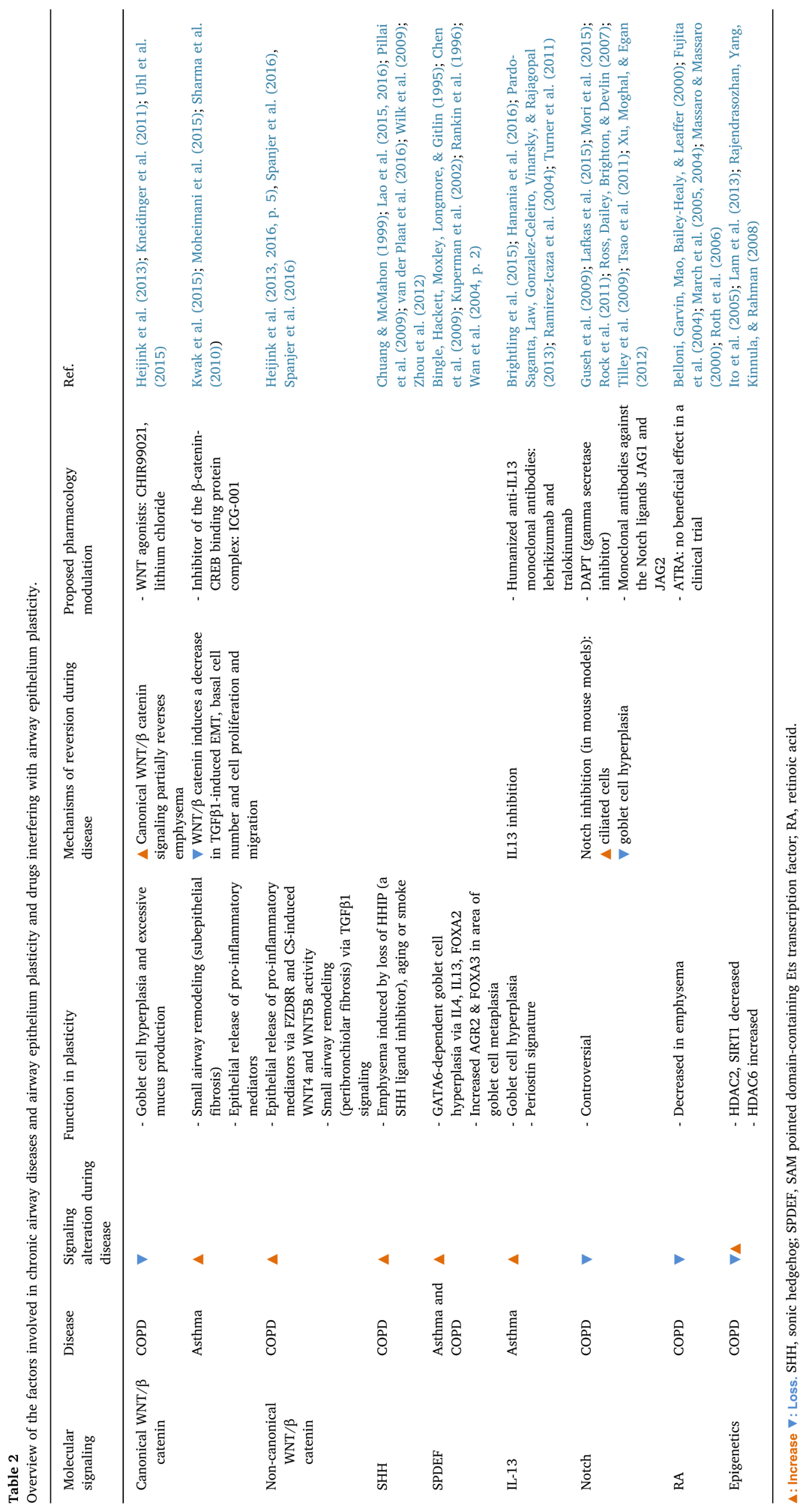


Motoyama, Orzalesi, \& Cook, 1971; Rooney et al., 1976). The introduction of GC treatment resulted in major changes in BDPrelated anatomical lesions and led to the concept of "old" and "new" BDP patterns (Jobe, 2011). Not only can glucocorticoids explain the difference between old and new BPD, but they can also likely explain the improved schemes of mechanical ventilation (Nelin \& Bhandari, 2017).

Moreover, as expression of sodium channels in epithelial airways correlates with cortisol level in preterm infants, it has been hypothesized that exogenous corticosteroids could stimulate alveolar fluid resorption in preterm infants (Janér, Pitkänen, Helve, \& Andersson, 2011).

Antenatal GC accelerate the development of both ATI and ATII cells, leading to structural and biochemical changes that improve lung mechanics and gas exchange (Ballard \& Ballard, 1995). Maturation of ATII cells by GC leads to increased surfactant production by inducing the production of surfactant proteins and enzymes necessary for phospholipid synthesis. GC can also upregulate fetal lung antioxidant enzymes (Grier \& Halliday, 2004). Induction of pulmonary beta-receptors is another effect of prenatal GC administration. This leads to surfactant release and absorption of alveolar fluid (Ballard \& Ballard, 1995).

GC are important physiological regulators of the pulmonary $\mathrm{Na}^{+}$ transport process (Matalon \& O'Brodovich, 1999; Matthay, Folkesson, \& Clerici, 2002). One of the most important GC effects in the context of prematurity is related to the control of $\mathrm{Na}^{+}$absorption in pulmonary epithelial cells by upregulation of the gene that encodes the epithelial $\mathrm{Na}^{+}$channel (ENaC), which has a role in lung fluid absorption (O'Brodovich, 1996).

GC control $\mathrm{Na}^{+}$absorption in pulmonary epithelial cells via a mechanism dependent on serum and glucocorticoid-inducible kinase 1 (SGK1), a kinase that regulates the amount of ENaC subunits ( $\alpha$-, $\beta$ - and $\gamma$ ) (Itani et al., 2002). In human fetal lungs, dexamethasone promotes the transcription of the genes that encode these three subunits (Venkatesh \& Katzberg, 1997).

Prenatal corticosteroids may also have a specific effect on the microvascular compartment. In an ovine model, repeated maternal administration of GC increased the activity of lung endothelial nitric oxide (NO) synthase in non-premature lambs (Grover, Ackerman, Le Cras, Jobe, \& Abman, 2000). Finally, GC may induce changes in the interstitial anatomical compartment by decreasing the septum thickness. These effects could be mediated through modulation of the proliferation/apoptosis balance of interstitial fibroblasts (Brenner et al., 2001).

In the clinic, antenatal GC administration is considered the gold standard treatment in pregnant women at high risk of premature delivery (Kemp, Newnham, Challis, Jobe, \& Stock, 2016; Roberts \& Dalziel, 2006). The antenatal use of GC reduces the complications associated with preterm delivery, such as neonatal respiratory distress syndrome (RSD), periventricular hemorrhage, necrotizing enterocolitis and, most importantly, neonatal mortality (Roberts, Brown, Medley, \& Dalziel, 2017). The beneficial respiratory effects are independent of postnatal surfactant therapy. However, even in combination with postnatal surfactants, corticosteroids do not reduce BPD incidence (Roberts \& Dalziel, 2006).

3.2.2.2. Postnatal corticosteroids. Physicians use postnatal GC in a curative way in the presence of severe (ventilator-dependent) RDS and as a rescue treatment in chronically ventilated preterm infants. In rats, GC strongly impair alveologenesis and microvascular growth when administered, even at very low dosage, during the first two weeks after birth. This effect is observed because it is used during the post-natal period of alveolar maturation. In humans, this would correspond to the first six months of postnatal life (Massaro \& Massaro, 1986) (see Fig. 1). The RA and GC signaling pathways are intricately linked, although the underlying molecular mechanisms have not been elucidated yet (Rush, Ul-Haq, \& Chytil, 1991). Indeed, RA treatment can antagonize GC effects on the termination of septation in rodents. It has been hypothesized that the postnatal side effect of steroids on lung development are caused by a too early microvascular fusion of capillaries. However, most of these data are highly controversial (Blanco \& Frank, 1993; Tschanz, Makanya, Haenni, \& Burri, 2003). This could explain the contradictory results reported on the postnatal effect of GC on lung growth. A recent Cochrane meta-analysis showed that early systemic administration of steroids ( $<7$ days after birth) facilitates extubation and decreases BPD prevalence in preterm infants (Doyle, Ehrenkranz, \& Halliday, 2014). However, the severity of the side effects supports the development of in-family drugs with safer profile, such as hydrocortisone (Doyle, Ehrenkranz, \& Halliday, 2010).

3.2.2.3. Inhaled steroids. The curative or preventive effects on RDS and BPD of inhaled steroid therapy in preterm babies needs to be confirmed in larger randomized, placebo-controlled trials. Data on its long-term respiratory effects are also needed. A recent meta-analysis showed that in extremely preterm infants treated with inhaled corticosteroids, BPD was less common without any mortality improvement (Shinwell, Portnov, Meerpohl, Karen, \& Bassler, 2016).

3.2.2.4. Exogenous surfactant proteins. The canalicular stage is characterized by two important steps of lung development: the differentiation of alveolar epithelial cells and the formation of the alveolar capillary barrier. Surfactant deficiency is one of the most important causes of RDS at birth (Akella \& Deshpande, 2013). As mentioned above, surfactant protein production can be stimulated by administration of corticosteroids between the 24th and 34th week of gestation to reduce the risk of acute RDS. Conversely, postnatal intratracheal administration of surfactant to prevent BPD is still debated, particularly because a recent meta-analysis (Beam et al., 2014) failed to show any benefit of surfactant in BPD prevention (Yeh et al., 2016).

3.2.2.5. Vascular targeted therapies. VEGF is highly expressed in alveolar septa. VEGF plays a central role in vasculogenesis and angiogenesis and is therefore critical for normal lung development in utero and also after birth (Jakkula et al., 2000; McGrath-Morrow et al., 2005). VEGF also has positive effects on ATII cell differentiation and stimulates surfactant production (Voelkel, Vandivier, \& Tuder, 2006). However, strict control of VEGF expression is necessary because VEGF overexpression is deleterious. Specifically, in neonatal mice, VEGF overexpression causes alveolar remodeling, inflammation and increases mortality (Le Cras et al., 2004). Neonatal lung injuries in animal models are associated with reduced VEGF expression (Thébaud \& Abman, 2007). Similarly, VEGF mRNA and protein expression are lower in human infants with BPD (Bhatt et al., 2001). In a neonatal rat model of irreversible hyperoxia, postnatal intra-tracheal administration of adenovirus-mediated VEGF gene therapy increased survival and alveolar development through improved lung capillary formation (Thébaud et al., 2005).

NO is a downstream VEGF signaling mediator during angiogenesis (Bhandari et al., 2008). In animal models of BPD, exposure to inhaled NO for several weeks leads to a remarkable improvement of lung function. In a model of pulmonary hypertension, inhaled NO attenuates pulmonary hypertension and partially corrects distal lung growth (Tang et al., 2004). Conversely, intraperitoneal administration of NO cannot improve survival and lung alveolarization (Lopez et al., 2006). NO is used in neonatology for BDP prevention, curative and rescue therapy, although evidences of its effects are still controversial (Ballard et al., 2006; Barrington \& Finer, 2010; Kinsella et al., 2006; Soll, 2012).

Sildenafil is a selective inhibitor of cGMP-specific phosphodiesterase type 5 that increases cGMP and is used to treat pulmonary hypertension. It can also improve alveolar growth in a rat model of human BPD (Ladha et al., 2005) and restore, by promoting vascularization, alveolarization following hyperoxia-induced impairment in preterm rodents (Park et al., 2013). These data suggest that phosphodiesterase type 5 could be targeted to drive alveolarization. Sildenafil has been 
used in term or near-term infants with persistent newborn pulmonary hypertension, but there is currently little evidence to support this use and additional prospective studies in patients with BPD associated with pulmonary hypertension are needed (Perez \& Laughon, 2015).

3.2.2.6. Thyroid hormones. Thyroid hormones play a role in epithelial and mesenchymal cell differentiation and airway branching during early lung development as well as in ATII cell differentiation and surfactant secretion during late lung development. In animals, administration of thyrotropin-releasing hormone (TRH), alone or in combination with corticosteroids, during pregnancy accelerates fetal lung maturation. High TRH doses increase ATII cell differentiation and distal airway maturation. These effects could be partially mediated by independent neuroendocrine pathways that also play a role as peripheral lung neurotransmitters (Ansari, Demello, Polk, \& Devaskar, 1997). In humans, clinical trials suggest that prenatal treatment with TRH and corticosteroids is better than corticosteroids alone in enhancing fetal lung maturation (Ballard et al., 1992; Knight, Liggins, \& Wealthall, 1994; Morales, O'Brien, Angel, Knuppel, \& Sawai, 1989).

3.2.2.7. Vitamin A/retinoic acid. RA is the active metabolite of vitamin A. Vitamin A is required in the fetal lung for both cell differentiation and surfactant synthesis and operates through nuclear receptors. Vitamin A and RA have similar effects on prenatal and postnatal lung development (Biesalski \& Nohr, 2003; Metzler \& Snyder, 1993). Both antenatal and postnatal corticosteroids significantly increase the plasma concentration of vitamin $\mathrm{A}$ in preterm infants. In a mouse model of GC-induced disruption of postnatal alveologenesis, RA promotes alveolar regeneration (Maden \& Hind, 2004; Massaro, Massaro, \& Chambon, 2003). RA also induces surfactant production (Ghanta, Leeman, \& Christou, 2013). The correlation between vitamin A concentration and biological effects has not been demonstrated yet, and patients with vitamin A deficiency can show clinical improvement without normalization of its plasma level (Robbins \& Fletcher, 1993) thus making difficult the interpretation of the supplementation efficacy. However, because of its toxicity, vitamin A levels must be carefully monitored. Infants with extremely low birth weight often show low plasma concentration and functionally deficient vitamin A during the first weeks of life. These features are associated with BDP development (Ambalavanan, Kennedy, Tyson, \& Carlo, 2004), supporting the hypothesis that vitamin A deficit contributes to the development of lung disease in preterm babies. A recent review that analyzed only studies with good methodology showed that only caffeine and vitamin A could prevent BPD without the risk of the adverse events induced by GC (Jensen, Foglia, \& Schmidt, 2015). However, overall, studies on the effects of vitamin A supplementation show discordant results, and prospective trials are required.

3.2.2.8. Fibroblasts growth factors. FGF7 can enhance lung repair in response to environmental injuries and may represent an alternative to GC because it does not affect lung growth. FGF7 is more abundant in tracheal aspirates from premature neonates without BPD than in those with BPD (Danan et al., 2002). Therapeutic administration of FGF7 to newborn rats exposed to hyperoxia prevents mortality, but does not rescue postnatal alveolar maturation (Franco-Montoya et al., 2009). The dosage and route of administration seem to be important for designing effective FGF7 treatments (Gesche et al., 2011).

3.2.2.9. Methylxanthines. Methylxanthines are purine bases and include many stimulants, such as pentoxifylline, aminophylline, theophylline, caffeine and theobromine. Caffeine, which is partially metabolized to theophylline, is one of the most prescribed drugs in neonatology. In preterm babies, caffeine is used both with curative and prophylactic intentions, by intravenous or endotracheal administration (Schmidt et al., 2006). Early caffeine administration ( $<72 \mathrm{~h}$ after birth) is associated with reduced BPD incidence in preterm infants
(Dobson et al., 2014; Ferguson, Roberts, Manley, \& Davis, 2016). Caffeine's beneficial effect could be correlated with a shorter time on positive pressure respiratory support. Some data suggest that it may also have peripheral effects. Indeed, caffeine enhances the ventilatory function through bronchodilation and improves diaphragm function (Kassim, Greenough, \& Rafferty, 2009). Moreover, in a cell culture model of human epithelial cells, caffeine can influence the expression of surfactant protein B mRNA (Fehrholz, Bersani, Kramer, Speer, \& Kunzmann, 2012).

3.2.2.10. Vitamin D. Vitamin D stimulates DNA synthesis in fetal and neonatal rat ATII cells, surfactant phospholipid synthesis and secretion by ATII cells, and postnatal alveolar growth (Lykkedegn, Sorensen, Beck-Nielsen, \& Christesen, 2015). The expression of vitamin D receptors in fetal lung cells during the late period of gestation, when ATII cells start to synthesize and secrete surfactant, suggests a biological association and/or regulation between vitamin $\mathrm{D}$ and distal lung airway maturation.

In a neonatal rat model, vitamin D improves oxygenation and survival after endotoxin exposure (Mandell, Seedorf, Gien, \& Abman, 2014). In humans, only one randomized control trial with a small number of preterm babies showed a reduced need for assisted ventilation in the high-dose vitamin D group (Backstrom et al., 1999).

\section{Therapeutic tools: iPSC enter the drug discovery pipeline}

Several drug types have been already marketed to treat bronchial and pulmonary diseases: anti-asthma, mucolytic and antitussive compounds, pulmonary surfactant, and respiratory analeptics. However, they offer mostly symptomatic treatment. The existing therapies for COPD modestly improve airflow and symptoms, and no currently available treatment significantly slows down disease progression or reverses the structural changes that compromise lung function. In asthma, the arrival of biotherapies represents an advance. These therapies have been reviewed extensively in previous issues of Pharmacology \& Therapeutics Journal. Here, we will focus on the role that iPSC can play in discovering new drugs thanks to their unparalleled capacity to recapitulate in vitro airway epithelial development and maintenance.

\subsection{Induced pluripotent stem cells: a new paradigm (Fig. 3)}

\subsubsection{The iPSC technology}

The iPSC technology emerged from the field of pluripotent stem cells (PSC). PSC display an infinite proliferation capacity and can potentially generate all body cell types (De Vos, Bouckenheimer, Sansac, Lemaître, \& Assou, 2016). In 1981, Evans and Kaufman (1981) and Martin (1981) derived the first embryonic stem cells (ESC) from early mouse embryos. Using the knowledge gained in the field of mouse ESC, Thomson et al. (1998) could later successfully isolate the first human ESC lines from the inner cell mass of preimplantation human embryos. Human ESC divide and self-renew for extensive periods of time, express PSC transcription factors, such as OCT4 and NANOG, can differentiate into all cell types from the three germ layers, and form teratomas when injected in immunocompromised mice. However, ethical issues, as well as the difficulty to obtain HLA-matched human PSC, stimulated the development of alternative methods for PSC derivation, particularly from the patient's own cells. In 2006, Takahashi and Yamanaka made the breakthrough discovery that by transiently expressing four transcription factors (OCT3/4, SOX2, KLF4 and C-Myc) using murine retroviruses, mouse somatic cells (embryonic or adult fibroblasts) could be reprogrammed into iPSC (Takahashi \& Yamanaka, 2006). In 2007, the first human iPSC line was created (Takahashi et al., 2007). Other combinations of transcription factors (for instance, OCT3/4, SOX2, NANOG and LIN28) (Yu et al., 2007) also have been 


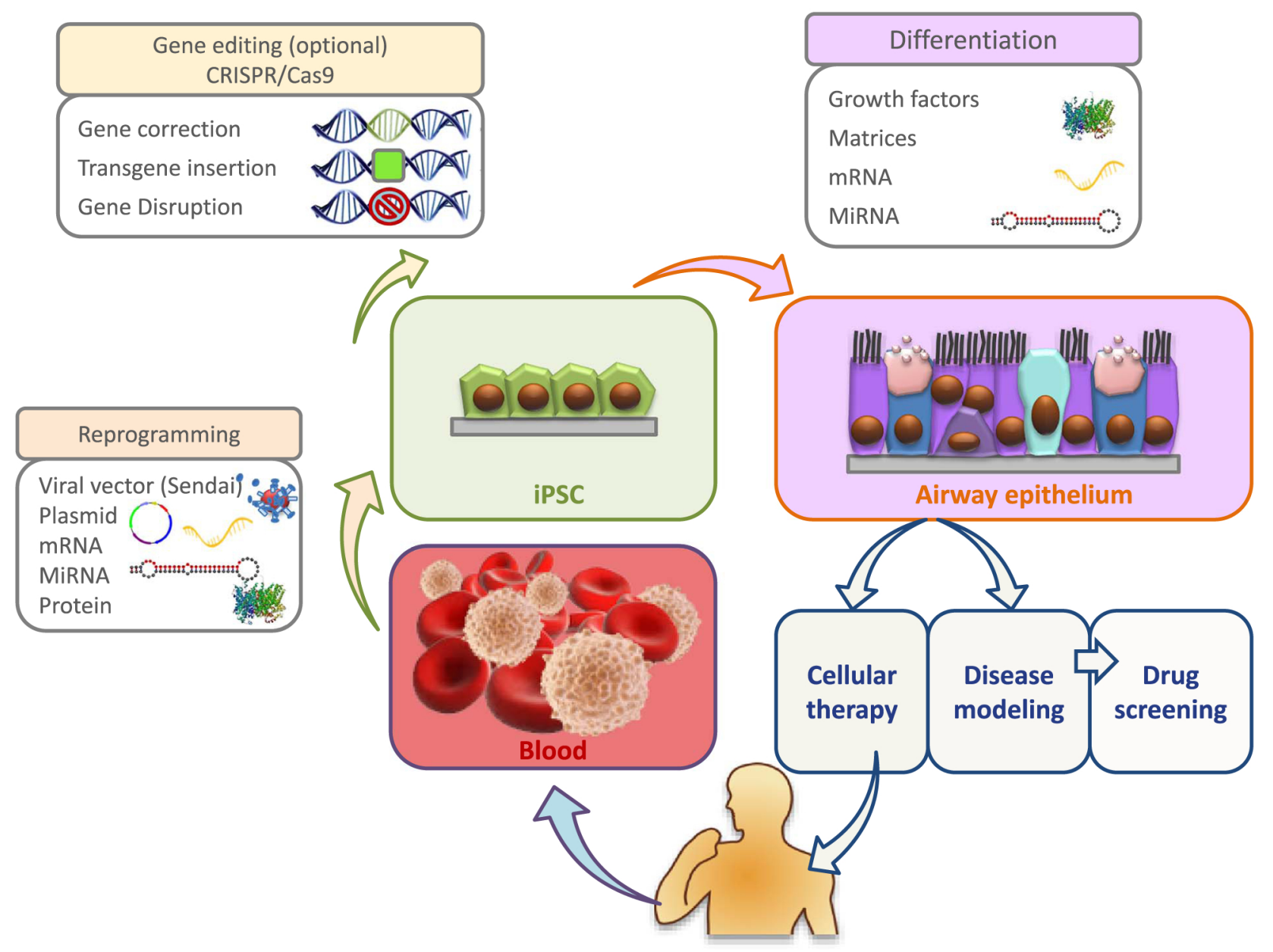

Fig. 3. Generation of patient-specific induced pluripotent stem cells (iPSC) and their applications for treating chronic airway diseases.

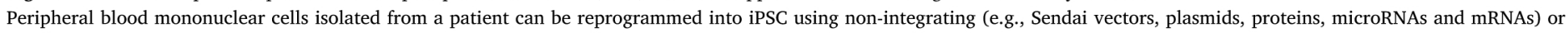

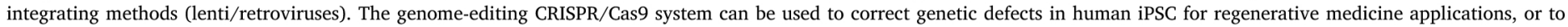

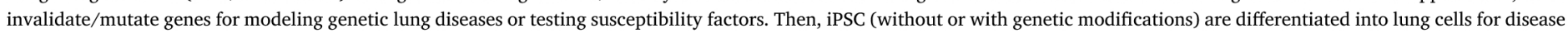

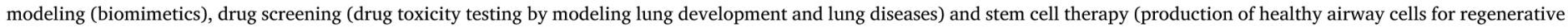
medicine). miRNA, microRNA; mRNA, messenger RNA.

successfully employed for iPSC production. Moreover, it has been shown that transgene integration into the genome, due to the use of lenti/retroviruses, is not necessary for reprogramming somatic cells into iPSC (Okita, Nakagawa, Hyenjong, Ichisaka, \& Yamanaka, 2008; Varas et al., 2009). Thus, non-integrating approaches have been developed to eliminate the risk of insertional mutagenesis, such as the use of Sendai RNA viruses (Fusaki, Ban, Nishiyama, Saeki, \& Hasegawa, 2009; Seki et al., 2010), plasmids, episomal vectors, mRNAs, microRNAs and even proteins (Huangfu et al., 2008; Miyazaki et al., 2012; Smiley, Stitt, \& Grusby, 1997; Su, Neises, \& Zhang, 2016; Yu et al., 2009) (Fig. 3). Furthermore, in mouse cells, the complete reprogramming process can be recapitulated also by using small molecules (Zhao et al., 2015). The issue of whether iPSC pluripotency features are comparable to those of ESC has been largely debated (Pera, 2011; Yamanaka, 2012). Recent and comprehensive studies have demonstrated that the epigenome, transcriptome and functionality of these two PSC types are indistinguishable (Choi et al., 2015; Féraud et al., 2016; Kyttälä et al., 2016; Rouhani et al., 2014; Vallier, 2015). Nevertheless, ESC will remain the gold standard for pluripotent cells because they are derived from embryos that contain pluripotent cells. Conversely, skin fibroblasts are the classical somatic cell type used as starting material for iPSC production. Other human cell types have been reprogrammed successfully into iPSC, such as mesenchymal stem cells, hair follicle keratinocytes, cord blood and peripheral blood mononuclear cells (Giorgetti et al., 2009; Lim et al., 2016; Ma et al., 2014).
Fibroblasts and particularly peripheral blood mononuclear cells are favored for iPSC production because they are easy to obtain and to reprogram (Diecke, Jung, Lee, \& Ju, 2014; Hayden, 2011). To produce clinically useful iPSC it is essential to use the best reprogramming method, choose the donor cell that best fits with the intended purpose, and ensure that the cells have not been genetically altered during iPSC production and amplification (Bai, Desprat, Klein, Lemaître, \& De Vos, 2013). An autologous donor cell source represents an advantage for regenerative medicine application because the risk of rejection is abolished. However, if the patient has a genetic disease, the genetic alteration remains in the iPSC and will appear after iPSC transplantation. This problem could be corrected in iPSC, for instance by using the CRISPR/Cas9 system (Li, Gee, Ishida, \& Hotta, 2016), and repaired human iPSC used to derive healthy specialized cells for transplantation (Fig. 3).

\subsubsection{Biomimetics to produce iPSC-derived airway tissues}

The most obvious way to differentiate iPSC into a specialized cell type is to mimic the specific development/differentiation processes. This strategy is a form of biomimetics whereby materials or systems are synthesized to mimic biological processes. In the case of iPSC-derived tissues, iPSC and their progeny are cultured in a specific medium that provides growth factors and micro-environmental cues in a correct and timely order that is as close as possible to the normal embryonic development (Table 3). For the production of airways cells, the very first stage to attain is the anterior primitive streak from which cells that will 
Critical embryological stages and molecules for iPSC differentiation into airway epithelium. Adapted from (Matsuno et al., 2016).

\begin{tabular}{|c|c|c|c|c|}
\hline Embryonic stage & Differentiation step & Molecules & Targets & Effects \\
\hline Inner cell mass & PSC & FGF2 & FGFR signaling & Pluripotency \\
\hline \multirow{5}{*}{$\begin{array}{l}\text { Anterior primitive streak } \\
\text { (APS) }\end{array}$} & \multirow[t]{5}{*}{ APS (24 h) } & Activin A & $\triangle$ Canonical TGF $\beta$ pathway & $\Delta$ Endoderm \\
\hline & & Low serum medium & $\nabla$ PI3kinase/AKT & $\nabla$ Posterior primitive streak \\
\hline & & CHIR99021 (GSK3 inhibitor) & $\triangle W N T$ & \\
\hline & & Y27632 (Rho kinase inhibitor) & VROCK & $\nabla$ Apoptosis \\
\hline & & & & $\nabla$ Ectoderm \\
\hline \multirow[t]{3}{*}{ Definitive endoderm (DE) } & \multirow[t]{3}{*}{$\mathrm{DE}(48 \mathrm{~h}-72 \mathrm{~h})$} & Activin A & $\triangle$ Canonical TGF $\beta$ pathway & $\Delta$ Definitive endoderm \\
\hline & & & $\triangle \mathrm{SMAD} 2 / 3$ phosphorylation & \\
\hline & & $\begin{array}{l}\text { LDN193189 (BMP signaling } \\
\text { inhibitor) }\end{array}$ & $\begin{array}{l}\nabla S M A D 1 / 5 / 8 \\
\text { phosphorylation }\end{array}$ & VMesoderm \\
\hline \multirow{2}{*}{$\begin{array}{l}\text { Anterior foregut endoderm } \\
\text { (AFE) }\end{array}$} & \multirow[t]{2}{*}{$\operatorname{AFE}(72 \mathrm{~h})$} & Low serum medium & VPI3kinase/AKT & $\triangle \mathrm{AFE}$ \\
\hline & & B27 w/o vitamin A & $\nabla$ Retinoic acid signaling & \\
\hline \multirow[t]{2}{*}{ Ventralized AFE } & \multirow[t]{2}{*}{ NKX2.1 + progenitors $(72 \mathrm{~h})$} & Low serum medium & $\nabla$ PI3kinase/AKT & $\triangle \mathrm{AFE}$ ventralization \\
\hline & & B27 w/o vitamin A & & \\
\hline \multirow[t]{12}{*}{ Bronchial epithelial cells } & \multirow{12}{*}{$\begin{array}{l}\text { Epithelium differentiation, maturation and } \\
\text { polarization }\end{array}$} & Air liquid interface & $\Delta \mathrm{RA}$ signaling & $\triangle$ Pseudoglandular phase \\
\hline & & BEGM medium with: & $\triangle F G F 10$ & $\triangle$ Canalicular phase \\
\hline & & & Thyroid hormone signaling & \\
\hline & & - RA & $\Delta$ Glucocorticoid signaling & \\
\hline & & - EGF & & \\
\hline & & - Transferrin & & \\
\hline & & - Epinephrine & & \\
\hline & & - Insulin & & \\
\hline & & - Bovine pituitary extract & & \\
\hline & & - Hydrocortisone & & \\
\hline & & - Tri-iodothyronine & & \\
\hline & & - FGF10 & & \\
\hline
\end{tabular}

$\Delta$ : Increase $\nabla$ : Loss.BEGM: bronchial epithelial cell growth medium.

form the endoderm delaminate. This is obtained mainly by exposing iPSC to WNT signaling and by blocking the PI3K pathway (Loh et al., 2016). As WNT family members are notoriously difficult to produce in vitro, WNT activation is usually obtained by blocking the GS3 kinase with the small molecule CHIR99021, while PI3K is inhibited by low serum culture conditions or with specific chemical inhibitors. The growth factor nodal is indispensable for the differentiation of anterior primitive streak cells into DE cells, from Xenopus laevis to human embryos. This effect can be mimicked in vitro by exposing cells to activin A, a member of the TGF $\beta$ superfamily that has similar properties as nodal, but is easier to manufacture. In addition, the simultaneous blockage of BMP signaling is necessary and can be obtained by using the soluble decoy noggin, or small molecules, such as LDN193189 (Matsuno et al., 2016). This step produces DE cells within a few days. These cells are characterized by the expression of the transcription factors FOXA2 and SOX17, and the surface chemokine receptor CXCR4. Upon concomitant blockage of the BMP and TGF $\beta$ signaling cascades (the latter can be inhibited for example with the small molecule SB431542), DE cells are differentiated into FOXA2 + SOX2 + anterior foregut endoderm (AFE). Activation of the WNT, BMP and FGF signaling cascades usually induces cells from the lung field of the foregut (i.e., ventral NKX2.1 + AFE cells). The production of lung progenitors and later of bronchial or alveolar epithelial cells is then possible by using FGF10 and ALI culture conditions with bronchial epithelial cell growth medium $\left(\mathrm{BEGM}^{\mathrm{TM}}\right)$. This schematic differentiation plan is based on the physiological cues that drive lung development and represents the smallest common denominator of all the protocols published to date about PSC differentiation into lung and airway cells (Dye et al., 2015; Firth et al., 2014; Huang et al., 2015; Konishi et al., 2016; Mou et al., 2012; Wong et al., 2015). It must be noted that there is large heterogeneity among protocols and the yields described in some of these studies are difficult to reproduce (Gomperts, 2014). This could be explained by the use of a specific PSC line with an advantageous bias towards lung cell fate, or to some technical details, such as the adaptation of the cell line to single-cell culture conditions (Wong et al., 2015). Overall, these reports have demonstrated that PSC can be differentiated into most cell types of the proximal and distal airways and alveoli, a feat that opens the way to cell therapy for lung diseases and lung disease modeling for drug screening.

\subsubsection{Cell therapy of lung diseases using iPSC}

Lung regenerative medicine could benefit from cell therapy approaches based on iPSC-derived lung cells. Indeed, a recent report showed that intravenously injected murine or human embryonic lung tissue cells at the canalicular stage of lung development display a marked capacity to repopulate the damaged lung of injured mice, resulting in pulmonary function similar to that of healthy, non-injured mice (Rosen et al., 2015). The key point of this work was the observation that stem cell competition must be limited by emptying the lung progenitor niche, as done for bone marrow transplantation. However, embryonic lung progenitors are difficult to obtain and anyway they would be allogeneic cells, therefore, iPSC-derived lung progenitors represent an ideal source of cells for lung cell therapy. The medical indications of such therapeutic approach have not been clearly defined, but it could be used at early disease stages before the lung architecture is irreversibly damaged. For instance, in COPD, where premature cell senescence might be involved (Aoshiba \& Nagai, 2009), such a strategy may be an interesting option.

4.1.4. In vitro lung disease modeling: the next stage in the development of lung disease treatments

Chronic airway disease modeling is still a challenge. For instance, COPD pathogenesis remains unexplained and in vitro COPD modeling could be essential to understand the underlying mechanisms in order to find new potential therapeutic targets. Although COPD animal models are acceptable for studying the inflammatory aspects and the consequences of the anatomical disruption of lung homeostasis, important discordances between these models and human COPD still need to be addressed (Wright, Cosio, \& Churg, 2008). It is moreover important to early identify at risk patients of developing COPD and this aim was already stated forty years ago because under-diagnosis in one hand and early intervention in the other hand are critical opportunities to prevent 
the natural course of the disease before patients become symptomatic. Virtually iPSC technology might be used to assess initiating steps of COPD development even by modeling in utero smoke exposure (by exposing cells all along the differentiating process) and we may take advantage of this to identify biological markers of susceptibility (Buist, 1975; Stănescu, Sanna, Veriter, \& Robert, 1998). For instance, in COPD animal models, most animals will develop COPD-like lesions when exposed to CS (Elias et al., 2006), differently from humans among whom only susceptible people will develop the disease. However, CS susceptibility differs among mouse strains, and therefore, the situation in mouse studies may not be so different compared with what is observed in humans. Nevertheless, no clear-cut finding from mouse studies could be translated into original mechanistic hypotheses. Furthermore, the rodent and human airway epithelia present important phenotypic and functional differences (Wright et al., 2008). ALI cultures of primary HBECs from patients with COPD are interesting systems to complement the findings obtained in animal models and offer unique advantages. First, they are a human cell model and can take into account the human heterogeneity in disease susceptibility. Second, they reproduce and maintain the COPD epithelial phenotypic signature even in culture (Gras et al., 2012; Pezzulo et al., 2011). Third, HBECs can be modulated using different stimuli and many functional features can be studied, from the release of cytokines to cilia beat frequency or mucociliary clearance (Gamez et al., 2015; Gras et al., 2012). Finally, all bronchial cell types are present and functional. However, ALI cultures of primary HBECs also present important disadvantages: long interval (two months or more) from the bronchial biopsy to the establishment of cells that can be used for experiments; limited production of epithelium surface; repeated requirement of new starting material; quite expensive system with variable success. Because of these limitations, each experiment requires a lot of samples. Although bronchoscopy is a routine procedure, ethical issues, time and costs limit the access to this model.

On the other hand, iPSC represent a real breakthrough in the field of lung diseases by bringing three unique features: the possibility to study the different steps of lung development (giving, thus, access to any immature or mature airway cell type), an unlimited supply of cells and the possibility of genetic modifications. Like all PSC, iPSC proliferate indefinitely with at least two cell population doublings per week. This overcomes one of the main limits of HBECs and also provides a window for genetic manipulation, for instance with the powerful CRISPR/Cas9 system (González et al., 2014; Merkert \& Martin, 2016). The use of the programmable Cas 9 nuclease opens the way to delete, insert or edit at the single base level the genome of any iPSC line (Fig. 3). Therefore, it could be possible to test the functional consequences of ablating any gene (one by one, or in combination) involved in lung development or homeostasis, or to ectopically express or delete candidate susceptibility factors to lung diseases and test the consequences in vitro (Musunuru, 2013). However, iPSC technology and handling are still facing significant concerns, such as high costs (culture media and growth factors) and iPSC genetic instability (Bai et al., 2013, 2015) when cells are cultured in stressful conditions.

For COPD, one of the most prevalent lung diseases, phenocopying the main disease features in iPSC-derived airway epithelium exposed to CS would provide a unique model to improve our understanding of this disease. Idiopathic pulmonary fibrosis is a rare disease supposedly caused by a defect in ATII cells. ATII cells cannot currently be expanded satisfactorily in vitro, but they can be produced from iPSC. Therefore, iPSC may provide a new reason to explore the mechanisms underlying this untreatable lung disease (Snoeck, 2015; Wong et al., 2015). Similarly, BPD cannot be modeled adequately in mice because of the different lung architecture and development compared with humans. As iPSC can recapitulate the complete lung development steps in vitro, they may provide a new way to understand BDP and develop efficient treatments.

iPSC are also a suitable tool for high-throughput small molecule screening, as already demonstrated for genetic nervous system diseases and ageing disorders (Blondel et al., 2016; Marchetto et al., 2010). They could also be used to model lung diseases. The unlimited iPSC production, the possibility to choose the starting cell genotype and/or to introduce genetic alterations using the CRISPR/Cas9 system make it possible to produce millions of diseased airway epithelial cells to screen chemical libraries. In addition, the possibility to test the toxicity of a drug on normal immature or adult airway epithelium will contribute to early drug validation during the drug discovery pipeline, thereby accelerating the development of efficient and safe new drugs. Recent reports on the in vitro production of mature bronchial or alveoli epithelial cells from iPSC (Wong et al., 2012) suggest that their use for lung drug screening could be rapidly implemented.

Another difficulty is to in vitro model an organ with a complex 3D architecture, such as the lung. Two strategies have been mainly used to solve this problem: i) the production of epithelium as an artificial flat layer on a matrix, like after the unfolding of a cylindrical or spherical lung structure, and ii) the differentiation of cells into spheres (called lung organoids) that mimic lung development, with the generation of hollow structures lined with epithelium. These promising functional models look more relevant than $2 \mathrm{D}$ culture systems, but at the moment no pharmacological application has been described (Aurora \& Spence, 2016; Dye et al., 2015; Nadkarni, Abed, \& Draper, 2016). Others strategies include alveolospheres, which are 3D alveolar-like structures derived from primary human ATII cells by co-culture with fetal human lung fibroblasts (Barkauskas et al., 2013), and microfluidics systems, such as lung-on a-chip. These systems could be more suitable for the rapid screening of small molecules (Service, 2012). Finally, another limitation is the absence of vascularization of these structures, particularly because lung epithelium co-develops and functions very closely with vessels (Peng \& Morrisey, 2013). The study of human iPSC-derived airway tissue in the context of a functional vasculature can only be envisioned by producing human-animal chimeras, as discussed elsewhere (Bourret et al., 2016).

\section{Conclusion}

Driving iPSC differentiation toward airway epithelial cells is a fascinating exercise where temporal and spatial sequential waves of expression and repression of key cell mediators must be mimicked. To this aim, a comprehensive panel of pharmacological molecules is currently developed with increasing levels of specificity and availability. The time course and dose response slopes are mostly unknown yet, but important data generated in cellular and animal models provide evidences that BMP, WNT, SHH and Notch are reachable targets. Whether the future will take advantage from these pharmacological steps directly or for the differentiation of iPSC (genetically modified or not) in view of therapeutic applications is an interesting matter of debate.

\section{Acknowledgment}

We thank E. Andermarcher for critical reading of this manuscript.

\section{Conflict of interest statement}

The authors declare that there are no conflicts of interest.

\section{References}

Ahdieh, M., Vandenbos, T., \& Youakim, A. (2001). Lung epithelial barrier function and wound healing are decreased by IL-4 and IL-13 and enhanced by IFN-gamma. American Journal of Physiology. Cell Physiology, 281, C2029-2038.

Akella, A., \& Deshpande, S. B. (2013). Pulmonary surfactants and their role in pathophysiology of lung disorders. Indian Journal of Experimental Biology, 51, 5-22.

Allen-Gipson, D. S., Zimmerman, M. C., Zhang, H., Castellanos, G., O’Malley, J. K., Alvarez-Ramirez, H., ... Wyatt, T. A. (2013). Smoke extract impairs adenosine wound healing: Implications of smoke-generated reactive oxygen species. American Journal of Respiratory Cell and Molecular Biology, 48, 665-673. http://dx.doi.org/10.1165/ rcmb.2011-02730C. 
Ambalavanan, N., Kennedy, K., Tyson, J., \& Carlo, W. A. (2004). Survey of vitamin A supplementation for extremely-low-birth-weight infants: Is clinical practice consistent with the evidence? The Journal of Pediatrics, 145, 304-307. http://dx.doi.org/ 10.1016/j.jpeds.2004.04.046.

Amsellem, V., Gary-Bobo, G., Marcos, E., Maitre, B., Chaar, V., Validire, P., ... Adnot, S. (2011). Telomere dysfunction causes sustained inflammation in chronic obstructive pulmonary disease. American Journal of Respiratory and Critical Care Medicine, 184, 1358-1366. http://dx.doi.org/10.1164/rccm.201105-0802OC.

Ansari, M. A., Demello, D. E., Polk, D. H., \& Devaskar, U. P. (1997). Thyrotropin-releasing hormone accelerates fetal mouse lung ultrastructural maturation via stimulation of extra thyroidal pathway. Pediatric Research, 42, 709-714. http://dx.doi.org/10.1203/ 00006450-199711000-00025.

Aoshiba, K., \& Nagai, A. (2009). Senescence hypothesis for the pathogenetic mechanism of chronic obstructive pulmonary disease. Proceedings of the American Thoracic Society, 6, 596-601. http://dx.doi.org/10.1513/pats.200904-017RM.

Aoyagi-Ikeda, K., Maeno, T., Matsui, H., Ueno, M., Hara, K., Aoki, Y., ... Kurabayashi, M. (2011). Notch induces myofibroblast differentiation of alveolar epithelial cells via transforming growth factor-\{beta\}-Smad3 pathway. American Journal of Respiratory Cell and Molecular Biology, 45, 136-144. http://dx.doi.org/10.1165/rcmb.200901400C.

Araya, J., Cambier, S., Markovics, J. A., Wolters, P., Jablons, D., Hill, A., ... Nishimura, S. L. (2007). Squamous metaplasia amplifies pathologic epithelial-mesenchymal interactions in COPD patients. The Journal of Clinical Investigation, 117, 3551-3562. http://dx.doi.org/10.1172/JCI32526.

Aurora, M., \& Spence, J. R. (2016). hPSC-derived lung and intestinal organoids as models of human fetal tissue. Developmental Biology, 420, 230-238. http://dx.doi.org/10, 1016/j.ydbio.2016.06.006.

Backstrom, M., Maki, R., Kuusela, A., Sievanen, H., Koivisto, A., Ikonen, R., ... Maki, M. (1999). Randomised controlled trial of vitamin D supplementation on bone density and biochemical indices in preterm infants. Archives of Disease in Childhood. Fetal and Neonatal Edition, 80, F161.

Bafadhel, M., McKenna, S., Terry, S., Mistry, V., Pancholi, M., Venge, P., ... Brightling, C. E. (2012). Blood eosinophils to direct corticosteroid treatment of exacerbations of chronic obstructive pulmonary disease: A randomized placebo-controlled trial. American Journal of Respiratory and Critical Care Medicine, 186, 48-55. http://dx.doi. org/10.1164/rccm.201108-15530C.

Bai, Q., Desprat, R., Klein, B., Lemaître, J.-M., \& De Vos, J. (2013). Embryonic stem cells or induced pluripotent stem cells? A DNA integrity perspective. Current Gene Therapy, 13, 93-98.

Bai, Q., Ramirez, J.-M., Becker, F., Pantesco, V., Lavabre-Bertrand, T., Hovatta, O., ... De Vos, J. (2015). Temporal analysis of genome alterations induced by single-cell passaging in human embryonic stem cells. Stem Cells and Development, 24, 653-662. http://dx.doi.org/10.1089/scd.2014.0292.

Ballard, P. L., \& Ballard, R. A. (1995). Scientific basis and therapeutic regimens for use of antenatal glucocorticoids. American Journal of Obstetrics and Gynecology, 173, 254-262.

Ballard, R. A., Ballard, P. L., Creasy, R. K., Padbury, J., Polk, D. H., Bracken, M., ... Gross, I. (1992). Respiratory disease in very-low-birthweight infants after prenatal thyrotropin-releasing hormone and glucocorticoid. TRH Study Group. Lancet (London, England), 339, 510-515.

Ballard, R. A., Truog, W. E., Cnaan, A., Martin, R. J., Ballard, P. L., Merrill, J. D., ... NO CLD Study Group (2006). Inhaled nitric oxide in preterm infants undergoing mechanical ventilation. The New England Journal of Medicine, 355, 343-353. http://dx. doi.org/10.1056/NEJMoa061088.

Barkauskas, C. E., Cronce, M. J., Rackley, C. R., Bowie, E. J., Keene, D. R., Stripp, B. R., ... Hogan, B. L. M. (2013). Type 2 alveolar cells are stem cells in adult lung. The Journal of Clinical Investigation, 123, 3025-3036. http://dx.doi.org/10.1172/JCI68782.

Barrington, K. J., \& Finer, N. (2010). Inhaled nitric oxide for respiratory failure in preterm infants. Cochrane Database of Systematic ReviewsCD000509. http://dx.doi.org/10. 1002/14651858.CD000509.pub4.

Beam, K. S., Aliaga, S., Ahlfeld, S. K., Cohen-Wolkowiez, M., Smith, P. B., \& Laughon, M. M. (2014). A systematic review of randomized controlled trials for the prevention of bronchopulmonary dysplasia in infants. Journal of Perinatology: Official Journal of the California Perinatal Association, 34, 705-710. http://dx.doi.org/10.1038/jp.2014. 126.

Beers, M. F., \& Morrisey, E. E. (2011). The three R's of lung health and disease: Repair, remodeling, and regeneration. The Journal of Clinical Investigation, 121, 2065-2073. http://dx.doi.org/10.1172/JCI45961.

Belloni, P. N., Garvin, L., Mao, C. P., Bailey-Healy, I., \& Leaffer, D. (2000). Effects of alltrans-retinoic acid in promoting alveolar repair. Chest, 117 (235S-41S).

Bhandari, V., Choo-Wing, R., Lee, C. G., Yusuf, K., Nedrelow, J. H., Ambalavanan, N., ... Elias, J. A. (2008). Developmental regulation of NO-mediated VEGF-induced effects in the lung. American Journal of Respiratory Cell and Molecular Biology, 39, 420-430. http://dx.doi.org/10.1165/rcmb.2007-00240C.

Bhatt, A. J., Pryhuber, G. S., Huyck, H., Watkins, R. H., Metlay, L. A., \& Maniscalco, W. M. (2001). Disrupted pulmonary vasculature and decreased vascular endothelial growth factor, Flt-1, and TIE-2 in human infants dying with bronchopulmonary dysplasia. American Journal of Respiratory and Critical Care Medicine, 164, 1971-1980. http://dx. doi.org/10.1164/ajrccm.164.10.2101140.

Biesalski, H. K., \& Nohr, D. (2003). Importance of vitamin-A for lung function and development. Molecular Aspects of Medicine, 24, 431-440.

Bingle, C. D., Hackett, B. P., Moxley, M., Longmore, W., \& Gitlin, J. D. (1995). Role of hepatocyte nuclear factor- 3 alpha and hepatocyte nuclear factor-3 beta in Clara cell secretory protein gene expression in the bronchiolar epithelium. Biochemical Journal, 308(Pt 1), 197-202.

Blanco, L. N., \& Frank, L. (1993). The formation of alveoli in rat lung during the third and fourth postnatal weeks: Effect of hyperoxia, dexamethasone, and deferoxamine. Pediatric Research, 34, 334-340. http://dx.doi.org/10.1203/00006450-19930900000019.

Blondel, S., Egesipe, A.-L., Picardi, P., Jaskowiak, A.-L., Notarnicola, M., Ragot, J., .. Nissan, X. (2016). Drug screening on Hutchinson Gilford progeria pluripotent stem cells reveals aminopyrimidines as new modulators of farnesylation. Cell Death \& Disease, 7, e2105. http://dx.doi.org/10.1038/cddis.2015.374.

Bolt, R. J., van Weissenbruch, M. M., Lafeber, H. N., \& Delemarre-van de Waal, H. A. (2001). Glucocorticoids and lung development in the fetus and preterm infant. Pediatric Pulmonology, 32, 76-91.

Bommart, S., Marin, G., Bourdin, A., Molinari, N., Klein, F., Hayot, M., ... VernhetKovacsik, H. (2014). Relationship between CT air trapping criteria and lung function in small airway impairment quantification. BMC Pulmonary Medicine, 14, 29. http:// dx.doi.org/10.1186/1471-2466-14-29.

Bommart, S., Marin, G., Bourdin, A., Revel, M. P., Klein, F., Hayot, M., ... VernhetKovacsik, H. (2015). Computed tomography quantification of airway remodelling in normal ageing subjects: A cross-sectional study. The European Respiratory Journal, 45, 1167-1170. http://dx.doi.org/10.1183/09031936.00215314.

Booth, B. W., Adler, K. B., Bonner, J. C., Tournier, F., \& Martin, L. D. (2001). Interleukin13 induces proliferation of human airway epithelial cells in vitro via a mechanism mediated by transforming growth factor-alpha. American Journal of Respiratory Cell and Molecular Biology, 25, 739-743. http://dx.doi.org/10.1165/ajrcmb.25.6.4659.

Bourdin, A., Kotsimbos, T., Nguyen, K., Vachier, I., Mainprice, B., Farce, M., ... Chanez, P. (2010). Non-invasive assessment of small airway remodelling in smokers. COPD, 7, 102-110. http://dx. doi.org/10.3109/15412551003631709.

Bourdin, A., Neveu, D., Vachier, I., Paganin, F., Godard, P., \& Chanez, P. (2007). Specificity of basement membrane thickening in severe asthma. The Journal of Allergy and Clinical Immunology, 119, 1367-1374. http://dx.doi.org/10.1016/j.jaci.2007.01. 055 .

Bourdin, A., Serre, I., Flamme, H., Vic, P., Neveu, D., Aubas, P., ... Chanez, P. (2004). Can endobronchial biopsy analysis be recommended to discriminate between asthma and COPD in routine practice? Thorax, 59, 488-493.

Bourret, R., Martinez, E., Vialla, F., Giquel, C., Thonnat-Marin, A., \& De Vos, J. (2016). Human-animal chimeras: Ethical issues about farming chimeric animals bearing human organs. Stem Cell Research \& Therapy, 7, 87. http://dx.doi.org/10.1186/ s13287-016-0345-9.

Boyer, L., Chouaïd, C., Bastuji-Garin, S., Marcos, E., Margarit, L., Le Corvoisier, P., ... Adnot, S. (2015). Aging-related systemic manifestations in COPD patients and cigarette smokers. PLoS One, 10, e0121539. http://dx.doi.org/10.1371/journal.pone. 0121539.

Brenner, R. E., Felger, D., Winter, C., Christiansen, A., Hofmann, D., \& Bartmann, P. (2001). Effects of dexamethasone on proliferation, chemotaxis, collagen I, and fibronectin-metabolism of human fetal lung fibroblasts. Pediatric Pulmonology, 32, 1-7.

Brightling, C. E., Chanez, P., Leigh, R., O'Byrne, P. M., Korn, S., She, D., ... Piper, E. (2015). Efficacy and safety of tralokinumab in patients with severe uncontrolled asthma: A randomised, double-blind, placebo-controlled, phase $2 \mathrm{~b}$ trial. The Lancet Respiratory Medicine, 3, 692-701. http://dx.doi.org/10.1016/S2213-2600(15) 00197-6.

Buist, A. S. (1975). New tests to assess lung function. The single-breath nitrogen test. The New England Journal of Medicine, 293, 438-440. http://dx.doi.org/10.1056/ NEJM197508282930907.

Bush, A. (2008). COPD: A pediatric disease. COPD, 5, 53-67. http://dx.doi.org/10.1080/ 15412550701815965.

Byers, D. E., Alexander-Brett, J., Patel, A. C., Agapov, E., Dang-Vu, G., Jin, X., Holtzman, M. J. (2013). Long-term IL-33-producing epithelial progenitor cells in chronic obstructive lung disease. The Journal of Clinical Investigation, 123, 3967-3982. http://dx.doi.org/10.1172/JCI65570.

Câmara, J., \& Jarai, G. (2010). Epithelial-mesenchymal transition in primary human bronchial epithelial cells is Smad-dependent and enhanced by fibronectin and TNFalpha. Fibrogenesis \& Tissue Repair, 3, 2. http://dx.doi.org/10.1186/1755-1536-3-2.

Chao, C.-M., El Agha, E., Tiozzo, C., Minoo, P., \& Bellusci, S. (2015). A breath of fresh air on the mesenchyme: Impact of impaired mesenchymal development on the pathogenesis of bronchopulmonary dysplasia. Frontiers in Medicine, 2, 27. http://dx.doi. org/10.3389/fmed.2015.00027.

Chen, Z.-H., Kim, H. P., Sciurba, F. C., Lee, S.-J., Feghali-Bostwick, C., Stolz, D. B., ... Choi, A. M. K. (2008). Egr-1 regulates autophagy in cigarette smoke-induced chronic obstructive pulmonary disease. PLoS One, 3, e3316. http://dx.doi.org/10.1371/journal. pone.0003316.

Chen, G., Korfhagen, T. R., Xu, Y., Kitzmiller, J., Wert, S. E., Maeda, Y., ... Whitsett, J. A. (2009). SPDEF is required for mouse pulmonary goblet cell differentiation and regulates a network of genes associated with mucus production. The Journal of Clinical Investigation, 119, 2914-2924. http://dx.doi.org/10.1172/JCI39731.

Choi, J., Lee, S., Mallard, W., Clement, K., Tagliazucchi, G. M., Lim, H., ... Hochedlinger, K. (2015). A comparison of genetically matched cell lines reveals the equivalence of human iPSCs and ESCs. Nature Biotechnology, 33, 1173-1181. http://dx.doi.org/10. $1038 /$ nbt.3388.

Chuang, P. T., \& McMahon, A. P. (1999). Vertebrate Hedgehog signalling modulated by induction of a Hedgehog-binding protein. Nature, 397, 617-621. http://dx.doi.org/ 10.1038/17611.

Cosio, M., Ghezzo, H., Hogg, J. C., Corbin, R., Loveland, M., Dosman, J., \& Macklem, P. T. (1978). The relations between structural changes in small airways and pulmonaryfunction tests. The New England Journal of Medicine, 298, 1277-1281. http://dx.doi. org/10.1056/NEJM197806082982303.

Crystal, R. G. (2014). Airway basal cells. The "smoking gun" of chronic obstructive pulmonary disease. American Journal of Respiratory and Critical Care Medicine, 190, 1355-1362. http://dx.doi.org/10.1164/rccm.201408-1492PP. 
Crystal, R. G., Randell, S. H., Engelhardt, J. F., Voynow, J., \& Sunday, M. E. (2008). Airway Epithelial Cells. Proceedings of the American Thoracic Society, 5, 772-777. http://dx.doi.org/10.1513/pats.200805-041HR.

Danan, C., Franco, M.-L., Jarreau, P.-H., Dassieu, G., Chailley-Heu, B., Bourbon, J., \& Delacourt, C. (2002). High concentrations of keratinocyte growth factor in airways of premature infants predicted absence of bronchopulmonary dysplasia. American Journal of Respiratory and Critical Care Medicine, 165, 1384-1387. http://dx.doi.org/ 10.1164/rccm.200112-134BC.

De Vos, J., Bouckenheimer, J., Sansac, C., Lemaître, J.-M., \& Assou, S. (2016). Human induced pluripotent stem cells: A disruptive innovation. Current Research in Translational Medicine, 64, 91-96. http://dx.doi.org/10.1016/j.retram.2016.04.001. Desai, L. P., Chapman, K. E., \& Waters, C. M. (2008). Mechanical stretch decreases migration of alveolar epithelial cells through mechanisms involving Rac1 and Tiam1. American Journal of Physiology. Lung Cellular and Molecular Physiology, 295, L958-965. http://dx.doi.org/10.1152/ajplung.90218.2008.

Diecke, S., Jung, S. M., Lee, J., \& Ju, J. H. (2014). Recent technological updates and clinical applications of induced pluripotent stem cells. The Korean Journal of Internal Medicine, 29, 547-557. http://dx.doi.org/10.3904/kjim.2014.29.5.547.

Dobson, N. R., Patel, R. M., Smith, P. B., Kuehn, D. R., Clark, J., Vyas-Read, S., ... Hunt, C. E. (2014). Trends in caffeine use and association between clinical outcomes and timing of therapy in very low birth weight infants. Journal of Pediatrics, 164, 992-998.e3. http://dx.doi.org/10.1016/j.jpeds.2013.12.025.

Donne, M. L., Lechner, A. J., \& Rock, J. R. (2015). Evidence for lung epithelial stem cell niches. BMC Developmental Biology, 15, 32. http://dx.doi.org/10.1186/s12861-0150082-9.

Doyle, L. W., Ehrenkranz, R. A., \& Halliday, H. L. (2010). Postnatal hydrocortisone for preventing or treating bronchopulmonary dysplasia in preterm infants: A systematic review. Neonatology, 98, 111-117. http://dx.doi.org/10.1159/000279992.

Doyle, L. W., Ehrenkranz, R. A., \& Halliday, H. L. (2014). Early ( $<8$ days) postnatal corticosteroids for preventing chronic lung disease in preterm infants. Cochrane Database of Systematic Reviews, CD001146. http://dx.doi.org/10.1002/14651858. CD001146.pub4.

Dye, B. R., Hill, D. R., Ferguson, M. A. H., Tsai, Y.-H., Nagy, M. S., Dyal, R., ... Spence, J. R. (2015). In vitro generation of human pluripotent stem cell derived lung organoids. eLife, 4. http://dx.doi.org/10.7554/eLife.05098.

Ekelund, L., Arvidson, G., Emanuelsson, H., Myhrberg, H., \& Astedt, B. (1975). Effect of cortisol on human fetal lung in organ culture: A biochemical, electron-microscopic and autoradiographic study. Cell and Tissue Research, 163, 263-272.

Elias, J. A., Kang, M. J., Crothers, K., Crouthers, K., Homer, R., \& Lee, C. G. (2006). State of the art. Mechanistic heterogeneity in chronic obstructive pulmonary disease: Insights from transgenic mice. Proceedings of the American Thoracic Society, 3, 494-498. http://dx.doi.org/10.1513/pats.200603-068MS.

Evans, M. J., \& Kaufman, M. H. (1981). Establishment in culture of pluripotential cells from mouse embryos. Nature, 292, 154-156.

Fahy, J. V., \& Dickey, B. F. (2010). Airway mucus function and dysfunction. The New England Journal of Medicine, 363, 2233-2247. http://dx.doi.org/10.1056/ NEJMra0910061.

Fehrholz, M., Bersani, I., Kramer, B. W., Speer, C. P., \& Kunzmann, S. (2012). Synergistic effect of caffeine and glucocorticoids on expression of surfactant protein B (SP-B) mRNA. PLoS One, 7, e51575. http://dx.doi.org/10.1371/journal.pone.0051575.

Féraud, O., Valogne, Y., Melkus, M. W., Zhang, Y., Oudrhiri, N., Haddad, R., ... MitjavilaGarcia, M. T. (2016). Donor dependent variations in hematopoietic differentiation among embryonic and induced pluripotent stem cell lines. PLoS One, 11, e0149291. http://dx.doi.org/10.1371/journal.pone.0149291.

Ferguson, K. N., Roberts, C. T., Manley, B. J., \& Davis, P. G. (2016). Interventions to improve rates of successful extubation in preterm infants: A systematic review and meta-analysis. JAMA Pediatrics. http://dx.doi.org/10.1001/jamapediatrics. 2016. 3015 .

Firth, A. L., Dargitz, C. T., Qualls, S. J., Menon, T., Wright, R., Singer, O., ... Verma, I. M. (2014). Generation of multiciliated cells in functional airway epithelia from human induced pluripotent stem cells. Proceedings of the National Academy of Sciences, 111, E1723-E1730. http://dx.doi.org/10.1073/pnas.1403470111.

Franco-Montoya, M.-L., Bourbon, J. R., Durrmeyer, X., Lorotte, S., Jarreau, P.-H., \& Delacourt, C. (2009). Pulmonary effects of keratinocyte growth factor in newborn rats exposed to hyperoxia. American Journal of Physiology. Lung Cellular and Molecular Physiology, 297, L965-976. http://dx.doi.org/10.1152/ajplung.00136.2009.

Fujii, S., Hara, H., Araya, J., Takasaka, N., Kojima, J., Ito, S., ... Kuwano, K. (2012). Insufficient autophagy promotes bronchial epithelial cell senescence in chronic obstructive pulmonary disease. Oncoimmunology, 1, 630-641. http://dx.doi.org/10. 4161/onci.20297.

Fujita, M., Ye, Q., Ouchi, H., Nakashima, N., Hamada, N., Hagimoto, N., ... Nakanishi, Y, (2004). Retinoic acid fails to reverse emphysema in adult mouse models. Thorax, 59, 224-230.

Fusaki, N., Ban, H., Nishiyama, A., Saeki, K., \& Hasegawa, M. (2009). Efficient induction of transgene-free human pluripotent stem cells using a vector based on Sendai virus, an RNA virus that does not integrate into the host genome. Proceedings of the Japan Academy. Series B, Physical and Biological Sciences, 85, 348-362.

Gallot, D., Marceau, G., Coste, K., Hadden, H., Robert-Gnansia, E., Laurichesse, H., ... Sapin, V. (2005). Congenital diaphragmatic hernia: A retinoid-signaling pathway disruption during lung development? Birth Defects Research, Part A: Clinical and Molecular Teratology, 73, 523-531. http://dx.doi.org/10.1002/bdra.20151.

Gamez, A. S., Gras, D., Petit, A., Knabe, L., Molinari, N., Vachier, I., ... Bourdin, A. (2015). Supplementing defect in club cell secretory protein attenuates airway inflammation in COPD. Chest, 147, 1467-1476. http://dx.doi.org/10.1378/chest.14-1174.

Gesche, J., Fehrenbach, H., Koslowski, R., Ohler, F. M., Pynn, C. J., Griese, M., Bernhard, W. (2011). rhKGF stimulates lung surfactant production in neonatal rats in vivo. Pediatric Pulmonology, 46, 882-895. http://dx.doi.org/10.1002/ppul.21443. Ghaedi, M., \& Niklason, L. E. (2016). Human pluripotent stem cells (iPSC) generation, culture, and differentiation to lung progenitor cells. Methods in Molecular Biology (Clifton, N.J.). http://dx.doi.org/10.1007/7651_2016_11.

Ghanta, S., Leeman, K. T., \& Christou, H. (2013). An update on pharmacologic approaches to bronchopulmonary dysplasia. Seminars in Perinatology, 37, 115-123. http://dx.doi. org/10.1053/j.semperi.2013.01.008.

Giorgetti, A., Montserrat, N., Aasen, T., Gonzalez, F., Rodríguez-Pizà, I., Vassena, R., .. Izpisua Belmonte, J. C. (2009). Generation of induced pluripotent stem cells from human cord blood using OCT4 and SOX2. Cell Stem Cell, 5, 353-357. http://dx.doi. org/10.1016/j.stem.2009.09.008.

Gohy, S. T., Hupin, C., Fregimilicka, C., Detry, B. R., Bouzin, C., Gaide Chevronay, H., .. Pilette, C. (2015). Imprinting of the COPD airway epithelium for dedifferentiation and mesenchymal transition. The European Respiratory Journal, 45, 1258-1272. http://dx.doi.org/10.1183/09031936.00135814.

Gomperts, B. N. (2014). Induction of multiciliated cells from induced pluripotent stem cells. Proceedings of the National Academy of Sciences of the United States of America, 111, 6120-6121. http://dx.doi.org/10.1073/pnas.1404414111.

González, F., Zhu, Z., Shi, Z.-D., Lelli, K., Verma, N., Li, Q. V., \& Huangfu, D. (2014). An iCRISPR platform for rapid, multiplexable, and inducible genome editing in human pluripotent stem cells. Cell Stem Cell, 15, 215-226. http://dx.doi.org/10.1016/j.stem. 2014.05.018.

Gras, D., Bourdin, A., Vachier, I., de Senneville, L., Bonnans, C., \& Chanez, P. (2012). An ex vivo model of severe asthma using reconstituted human bronchial epithelium. The Journal of Allergy and Clinical Immunology, 129, 1259-1266.e1. http://dx.doi.org/10. 1016/j.jaci.2012.01.073.

Gras, D., Chanez, P., Vachier, I., Petit, A., \& Bourdin, A. (2013). Bronchial epithelium as a target for innovative treatments in asthma. Pharmacology \& Therapeutics, 140 , 290-305. http://dx.doi.org/10.1016/j.pharmthera.2013.07.008.

Grier, D. G., \& Halliday, H. L. (2004). Effects of glucocorticoids on fetal and neonatal lung development. Treatments in Respiratory Medicine, 3, 295-306.

Grover, T. R., Ackerman, K. G., Le Cras, T. D., Jobe, A. H., \& Abman, S. H. (2000). Repetitive prenatal glucocorticoids increase lung endothelial nitric oxide synthase expression in ovine fetuses delivered at term. Pediatric Research, 48, 75-83. http://dx. doi.org/10.1203/00006450-200007000-00014.

Guerra, S., Halonen, M., Vasquez, M. M., Spangenberg, A., Stern, D. A., Morgan, W. J., ... Martinez, F. D. (2015). Relation between circulating CC16 concentrations, lung function, and development of chronic obstructive pulmonary disease across the lifespan: A prospective study. The Lancet Respiratory Medicine, 3, 613-620. http://dx. doi.org/10.1016/S2213-2600(15)00196-4.

Guseh, J. S., Bores, S. A., Stanger, B. Z., Zhou, Q., Anderson, W. J., Melton, D. A., \& Rajagopal, J. (2009). Notch signaling promotes airway mucous metaplasia and inhibits alveolar development. Development (Cambridge, England), 136, 1751-1759. http://dx.doi.org/10.1242/dev.029249.

Habibovic, A., Hristova, M., Heppner, D. E., Danyal, K., Ather, J. L., Janssen-Heininger, Y. M. W., ... van der Vliet, A. (2016). DUOX1 mediates persistent epithelial EGFR activation, mucous cell metaplasia, and airway remodeling during allergic asthma. JCI Insight, 1, e88811. http://dx.doi.org/10.1172/jci.insight.88811.

Hackett, T.-L., de Bruin, H. G., Shaheen, F., van den Berge, M., van Oosterhout, A. J., Postma, D. S., \& Heijink, I. H. (2013). Caveolin-1 controls airway epithelial barrier function. Implications for asthma. American Journal of Respiratory Cell and Molecular Biology, 49, 662-671. http://dx.doi.org/10.1165/rcmb.2013-0124OC.

Hackett, N. R., Shaykhiev, R., Walters, M. S., Wang, R., Zwick, R. K., Ferris, B., ... Crystal, R. G. (2011). The human airway epithelial basal cell transcriptome. PLoS One, 6, e18378. http://dx.doi.org/10.1371/journal.pone.0018378.

Hackett, T.-L., Singhera, G. K., Shaheen, F., Hayden, P., Jackson, G. R., Hegele, R. G., .. Knight, D. A. (2011). Intrinsic phenotypic differences of asthmatic epithelium and its inflammatory responses to respiratory syncytial virus and air pollution. American Journal of Respiratory Cell and Molecular Biology, 45, 1090-1100. http://dx.doi.org/ 10.1165/rcmb.2011-00310C.

Hackett, T.-L., Warner, S. M., Stefanowicz, D., Shaheen, F., Pechkovsky, D. V., Murray, L. A., ... Knight, D. A. (2009). Induction of epithelial-mesenchymal transition in primary airway epithelial cells from patients with asthma by transforming growth factorbeta1. American Journal of Respiratory and Critical Care Medicine, 180, 122-133. http://dx.doi.org/10.1164/rccm.200811-17300C.

Hanania, N. A., Korenblat, P., Chapman, K. R., Bateman, E. D., Kopecky, P., Paggiaro, P., ... Matthews, J. G. (2016). Efficacy and safety of lebrikizumab in patients with uncontrolled asthma (LAVOLTA I and LAVOLTA II): Replicate, phase 3, randomised, double-blind, placebo-controlled trials. The Lancet Respiratory Medicine, 4, 781-796. http://dx.doi.org/10.1016/S2213-2600(16)30265-X.

Hanssens, M., Keirse, M. J., Vankelecom, F., \& Van Assche, F. A. (1991). Fetal and neo natal effects of treatment with angiotensin-converting enzyme inhibitors in pregnancy. Obstetrics and Gynecology, 78, 128-135.

Hayden, E. C. (2011). California ponders cell-banking venture. Nature, 472, 403. http:// dx.doi.org/10.1038/472403a.

Heijink, I. H., Brandenburg, S. M., Postma, D. S., \& van Oosterhout, A. J. M. (2012). Cigarette smoke impairs airway epithelial barrier function and cell-cell contact recovery. The European Respiratory Journal, 39, 419-428. http://dx.doi.org/10.1183/ 09031936.00193810.

Heijink, I. H., de Bruin, H. G., Dennebos, R., Jonker, M. R., Noordhoek, J. A., Brandsma, C.-A., ... Postma, D. S. (2016). Cigarette smoke-induced epithelial expression of WNT5B: Implications for COPD. The European Respiratory Journal, 48, 504-515. http://dx. doi.org/10.1183/13993003.01541-2015.

Heijink, I. H., de Bruin, H. G., van den Berge, M., Bennink, L. J. C., Brandenburg, S. M., Gosens, R., ... Postma, D. S. (2013). Role of aberrant WNT signalling in the airway epithelial response to cigarette smoke in chronic obstructive pulmonary disease. 
Thorax, 68, 709-716. http://dx.doi.org/10.1136/thoraxjnl-2012-201667.

Heijink, I. H., Nawijn, M. C., \& Hackett, T.-L. (2014). Airway epithelial barrier function regulates the pathogenesis of allergic asthma. Clinical and Experimental Allergy: Journal of the British Society for Allergy \& Clinical Immunology, 44, 620-630. http://dx. doi.org/10.1111/cea.12296.

Heijink, I. H., Noordhoek, J. A., Timens, W., van Oosterhout, A. J. M., \& Postma, D. S. (2014). Abnormalities in airway epithelial junction formation in chronic obstructive pulmonary disease. American Journal of Respiratory and Critical Care Medicine, 189, 1439-1442. http://dx.doi.org/10.1164/rccm.201311-1982LE.

Heijink, I. H., Postma, D. S., Noordhoek, J. A., Broekema, M., \& Kapus, A. (2010). House dust mite-promoted epithelial-to-mesenchymal transition in human bronchial epithelium. American Journal of Respiratory Cell and Molecular Biology, 42, 69-79. http:// dx.doi.org/10.1165/rcmb.2008-04490C.

Heijink, I. H., van Oosterhout, A., \& Kapus, A. (2010). Epidermal growth factor receptor signalling contributes to house dust mite-induced epithelial barrier dysfunction. The European Respiratory Journal, 36, 1016-1026. http://dx.doi.org/10.1183/09031936. 00125809.

Herriges, M., \& Morrisey, E. E. (2014). Lung development: Orchestrating the generation and regeneration of a complex organ. Development (Cambridge, England), 141, 502-513. http://dx.doi.org/10.1242/dev.098186.

Hislop, A. A. (2002). Airway and blood vessel interaction during lung development. Journal of Anatomy, 201, 325-334.

Hogg, J. C., Chu, F., Utokaparch, S., Woods, R., Elliott, W. M., Buzatu, L., ... Paré, P. D. (2004). The nature of small-airway obstruction in chronic obstructive pulmonary disease. The New England Journal of Medicine, 350, 2645-2653. http://dx.doi.org/10. 1056/NEJMoa032158.

Holgate, S. T. (2007). Epithelium dysfunction in asthma. The Journal of Allergy and Clinical Immunology, 120, 1233-1244. (quiz 1245-1246) https://doi.org/10.1016/j.jaci.2007. 10.025 .

Holgate, S. T. (2008). The airway epithelium is central to the pathogenesis of asthma. Allergology International: Official Journal of the Japanese Society of Allergology, 57, 1-10. http://dx.doi.org/10.2332/allergolint.R-07-154.

Holtzman, M. J., Byers, D. E., Alexander-Brett, J., \& Wang, X. (2014). The role of airway epithelial cells and innate immune cells in chronic respiratory disease. Nature Reviews. Immunology, 14, 686-698. http://dx.doi.org/10.1038/nri3739.

Huang, S. X. L., Green, M. D., de Carvalho, A. T., Mumau, M., Chen, Y.-W., D'Souza, S. L., \& Snoeck, H.-W. (2015). The in vitro generation of lung and airway progenitor cells from human pluripotent stem cells. Nature Protocols, 10, 413-425. http://dx.doi.org/ 10.1038/nprot.2015.023.

Huangfu, D., Osafune, K., Maehr, R., Guo, W., Eijkelenboom, A., Chen, S., ... Melton, D. A. (2008). Induction of pluripotent stem cells from primary human fibroblasts with only Oct4 and Sox2. Nature Biotechnology, 26, 1269-1275. http://dx.doi.org/10.1038/nbt. 1502.

Innes, A. L., Woodruff, P. G., Ferrando, R. E., Donnelly, S., Dolganov, G. M., Lazarus, S. C., \& Fahy, J. V. (2006). Epithelial mucin stores are increased in the large airways of smokers with airflow obstruction. Chest, 130, 1102-1108. http://dx.doi.org/10. 1378/chest.130.4.1102.

Itani, O. A., Auerbach, S. D., Husted, R. F., Volk, K. A., Ageloff, S., Knepper, M. A., ... Thomas, C. P. (2002). Glucocorticoid-stimulated lung epithelial $\mathrm{Na}(+)$ transport is associated with regulated ENaC and sgk1 expression. American Journal of Physiology. Lung Cellular and Molecular Physiology, 282, L631-641. http://dx.doi.org/10.1152/ ajplung.00085.2001.

Ito, K., Ito, M., Elliott, W. M., Cosio, B., Caramori, G., Kon, O. M., ... Barnes, P. J. (2005). Decreased histone deacetylase activity in chronic obstructive pulmonary disease. The New England Journal of Medicine, 352, 1967-1976. http://dx.doi.org/10.1056/ NEJMoa041892.

Jakkula, M., Le Cras, T. D., Gebb, S., Hirth, K. P., Tuder, R. M., Voelkel, N. F., \& Abman, S. $\mathrm{H}$. (2000). Inhibition of angiogenesis decreases alveolarization in the developing rat lung. American Journal of Physiology. Lung Cellular and Molecular Physiology, 279, L600-607.

Janér, C., Pitkänen, O. M., Helve, O., \& Andersson, S. (2011). Airway expression of the epithelial sodium channel $\alpha$-subunit correlates with cortisol in term newborns. Pediatrics, 128, e414-421. http://dx.doi.org/10.1542/peds.2011-0167.

Jensen, E. A., Foglia, E. E., \& Schmidt, B. (2015). Evidence-based pharmacologic therapies for prevention of bronchopulmonary dysplasia: Application of the grading of recommendations assessment, development, and evaluation methodology. Clinics in Perinatology, 42, 755-779. http://dx.doi.org/10.1016/j.clp.2015.08.005.

Jobe, A. H. (2011). The new bronchopulmonary dysplasia. Current Opinion in Pediatrics, 23, 167-172. http://dx.doi.org/10.1097/MOP.0b013e3283423e6b.

Johnson, J. R., Roos, A., Berg, T., Nord, M., \& Fuxe, J. (2011). Chronic respiratory aeroallergen exposure in mice induces epithelial-mesenchymal transition in the large airways. PLoS One, 6, e16175. http://dx.doi.org/10.1371/journal.pone.0016175.

Kajstura, J., Rota, M., Hall, S. R., Hosoda, T., D'Amario, D., Sanada, F., ... Anversa, P. (2011). Evidence for human lung stem cells. The New England Journal of Medicine, 364, 1795-1806. http://dx.doi.org/10.1056/NEJMoa1101324.

Kalluri, R., \& Weinberg, R. A. (2009). The basics of epithelial-mesenchymal transition The Journal of Clinical Investigation, 119, 1420-1428. http://dx.doi.org/10.1172/ JCI39104.

Kassim, Z., Greenough, A., \& Rafferty, G. F. (2009). Effect of caffeine on respiratory muscle strength and lung function in prematurely born, ventilated infants. European Journal of Pediatrics, 168, 1491-1495. http://dx.doi.org/10.1007/s00431-009 0961-9.

Kemp, M. W., Newnham, J. P., Challis, J. G., Jobe, A. H., \& Stock, S. J. (2016). The clinical use of corticosteroids in pregnancy. Human Reproduction Update, 22, 240-259. http:// dx.doi.org/10.1093/humupd/dmv047.

Kikkawa, Y., Kaibara, M., Motoyama, E. K., Orzalesi, M. M., \& Cook, C. D. (1971)
Morphologic development of fetal rabbit lung and its acceleration with cortisol. The American Journal of Pathology, 64, 423-442.

Kinsella, J. P., Cutter, G. R., Walsh, W. F., Gerstmann, D. R., Bose, C. L., Hart, C., .. Abman, S. H. (2006). Early inhaled nitric oxide therapy in premature newborns with respiratory failure. The New England Journal of Medicine, 355, 354-364. http://dx.doi. org/10.1056/NEJMoa060442.

Knabe, L., Fort, A., Chanez, P., \& Bourdin, A. (2015). Club cells and CC16: Another "smoking gun"? (With potential bullets against COPD). The European Respiratory Journal, 45, 1519-1520. http://dx.doi.org/10.1183/09031936.00010515.

Kneidinger, N., Yildirim, A.Ö., Callegari, J., Takenaka, S., Stein, M. M., Dumitrascu, R., .. Königshoff, M. (2011). Activation of the WNT/ $\beta$-catenin pathway attenuates experimental emphysema. American Journal of Respiratory and Critical Care Medicine, 183, 723-733. http://dx.doi.org/10.1164/rccm.200910-15600C.

Knight, D. B., Liggins, G. C., \& Wealthall, S. R. (1994). A randomized, controlled trial of antepartum thyrotropin-releasing hormone and betamethasone in the prevention of respiratory disease in preterm infants. American Journal of Obstetrics and Gynecology, 171, 11-16.

Königshoff, M., Kramer, M., Balsara, N., Wilhelm, J., Amarie, O. V., Jahn, A., .. Eickelberg, O. (2009). WNT1-inducible signaling protein-1 mediates pulmonary fibrosis in mice and is upregulated in humans with idiopathic pulmonary fibrosis. The Journal of Clinical Investigation, 119, 772-787. http://dx.doi.org/10.1172/JCI33950.

Konishi, S., Gotoh, S., Tateishi, K., Yamamoto, Y., Korogi, Y., Nagasaki, T., ... Mishima, M. (2016). Directed induction of functional multi-ciliated cells in proximal airway epithelial spheroids from human pluripotent stem cells. Stem Cell Reports, 6, 18-25. http://dx.doi.org/10.1016/j.stemcr.2015.11.010.

Kotton, D. N., \& Morrisey, E. E. (2014). Lung regeneration: Mechanisms, applications and emerging stem cell populations. Nature Medicine, 20, 822-832. http://dx.doi.org/10. 1038/nm.3642.

Kugler, M. C., Joyner, A. L., Loomis, C. A., \& Munger, J. S. (2015). Sonic hedgehog signaling in the lung. From development to disease. American Journal of Respiratory Cell and Molecular Biology, 52, 1-13. http://dx.doi.org/10.1165/rcmb.2014-0132TR.

Kuperman, D. A., Huang, X., Koth, L. L., Chang, G. H., Dolganov, G. M., Zhu, Z., ... Erle, D. J. (2002). Direct effects of interleukin-13 on epithelial cells cause airway hyperreactivity and mucus overproduction in asthma. Nature Medicine, 8, 885-889. http://dx.doi.org/10.1038/nm734.

Kwak, H. J., Park, D. W., Seo, J.-Y., Moon, J.-Y., Kim, T. H., Sohn, J. W., ... Kim, S.-H. (2015). The Wnt/ß-catenin signaling pathway regulates the development of airway remodeling in patients with asthma. Experimental \& Molecular Medicine, 47, e198. http://dx.doi.org/10.1038/emm.2015.91.

Kyttälä, A., Moraghebi, R., Valensisi, C., Kettunen, J., Andrus, C., Pasumarthy, K. K., ... Trokovic, R. (2016). Genetic variability overrides the impact of parental cell type and determines iPSC differentiation potential. Stem Cell Reports, 6, 200-212. http://dx. doi.org/10.1016/j.stemcr.2015.12.009.

Ladha, F., Bonnet, S., Eaton, F., Hashimoto, K., Korbutt, G., \& Thébaud, B. (2005). Sildenafil improves alveolar growth and pulmonary hypertension in hyperoxia-induced lung injury. American Journal of Respiratory and Critical Care Medicine, 172, 750-756. http://dx.doi.org/10.1164/rccm.200503-5100C.

Lafkas, D., Shelton, A., Chiu, C., de Leon Boenig, G., Chen, Y., Stawicki, S. S., ... Siebel, C. W. (2015). Therapeutic antibodies reveal Notch control of transdifferentiation in the adult lung. Nature, 528, 127-131. http://dx.doi.org/10.1038/nature15715.

Lagente, V., Manoury, B., Nénan, S., Le Quément, C., Martin-Chouly, C., \& Boichot, E. (2005). Role of matrix metalloproteinases in the development of airway inflammation and remodeling. Brazilian Journal of Medical and Biological Research Revista Brasileira de Pesquisas Médicas e Biológicas, 38, 1521-1530. http://dx.doi.org/10. 1590/S0100-879X2005001000009.

Lam, H. C., Cloonan, S. M., Bhashyam, A. R., Haspel, J. A., Singh, A., Sathirapongsasuti, J. F., ... Choi, A. M. K. (2013). Histone deacetylase 6-mediated selective autophagy regulates COPD-associated cilia dysfunction. The Journal of Clinical Investigation, 123, 5212-5230. http://dx.doi.org/10.1172/JCI69636.

Lambrecht, B. N., \& Hammad, H. (2012). The airway epithelium in asthma. Nature Medicine, 18, 684-692. http://dx.doi.org/10.1038/nm.2737.

Lange, P., Celli, B., Agustí, A., Boje Jensen, G., Divo, M., Faner, R., ... Vestbo, J. (2015). Lung-function trajectories leading to chronic obstructive pulmonary disease. The New England Journal of Medicine, 373, 111-122. http://dx.doi.org/10.1056/ NEJMoa1411532.

Lao, T., Glass, K., Qiu, W., Polverino, F., Gupta, K., Morrow, J., ... Zhou, X. (2015). Haploinsufficiency of Hedgehog interacting protein causes increased emphysema induced by cigarette smoke through network rewiring. Genome Medicine, 7, 12. http://dx.doi.org/10.1186/s13073-015-0137-3.

Lao, T., Jiang, Z., Yun, J., Qiu, W., Guo, F., Huang, C., ... Zhou, X. (2016). Hhip haploinsufficiency sensitizes mice to age-related emphysema. Proceedings of the National Academy of Sciences of the United States of America, 113, E4681-4687. http://dx.doi. org/10.1073/pnas.1602342113.

Laucho-Contreras, M. E., Polverino, F., Gupta, K., Taylor, K. L., Kelly, E., Pinto-Plata, V., Owen, C. A. (2015). Protective role for club cell secretory protein-16 (CC16) in the development of COPD. The European Respiratory Journal, 45, 1544-1556. http://dx. doi.org/10.1183/09031936.00134214.

Le Cras, T. D., Spitzmiller, R. E., Albertine, K. H., Greenberg, J. M., Whitsett, J. A., \& Akeson, A. L. (2004). VEGF causes pulmonary hemorrhage, hemosiderosis, and air space enlargement in neonatal mice. American Journal of Physiology. Lung Cellular and Molecular Physiology, 287, L134-142. http://dx.doi.org/10.1152/ajplung.00050. 2004.

Lechapt-Zalcman, E., Prulière-Escabasse, V., Advenier, D., Galiacy, S., Charrière-Bertrand, C., Coste, A., ... Escudier, E. (2006). Transforming growth factor-beta1 increases airway wound repair via MMP-2 upregulation: A new pathway for epithelial wound repair? American Journal of Physiology. Lung Cellular and Molecular Physiology, 290, 
L1277-1282. http://dx.doi.org/10.1152/ajplung.00149.2005.

Leinwand, M. J., Tefft, J. D., Zhao, J., Coleman, C., Anderson, K. D., \& Warburton, D. (2002). Nitrofen inhibition of pulmonary growth and development occurs in the early embryonic mouse. Journal of Pediatric Surgery, 37, 1263-1268.

Li, H. L., Gee, P., Ishida, K., \& Hotta, A. (2016). Efficient genomic correction methods in human iPS cells using CRISPR-Cas9 system. Methods (San Diego, Calif.), 101, 27-35. http://dx.doi.org/10.1016/j.ymeth.2015.10.015.

Li, X. L., Hara, T., Choi, Y., Subramanian, M., Francis, P., Bilke, S., ... Lal, A. (2014). A p21-ZEB1 complex inhibits epithelial-mesenchymal transition through the microRNA 183-96-182 cluster. Molecular and Cellular Biology, 34, 533-550. http://dx.doi.org/ 10.1128/MCB.01043-13.

Lim, S. J., Ho, S. C., Mok, P. L., Tan, K. L., Ong, A. H. K., \& Gan, S. C. (2016). Induced pluripotent stem cells from human hair follicle keratinocytes as a potential source for in vitro hair follicle cloning. PeerJ, 4, e2695. http://dx.doi.org/10.7717/peerj.2695.

Loh, K. M., Chen, A., Koh, P. W., Deng, T. Z., Sinha, R., Tsai, J. M., ... Weissman, I. L. (2016). Mapping the pairwise choices leading from pluripotency to human bone, heart, and other mesoderm cell types. Cell, 166, 451-467. http://dx.doi.org/10. 1016/j.cell.2016.06.011.

Lopez, E., Boucherat, O., Franco-Montoya, M.-L., Bourbon, J. R., Delacourt, C., \& Jarreau, P.-H. (2006). Nitric oxide donor restores lung growth factor and receptor expression in hyperoxia-exposed rat pups. American Journal of Respiratory Cell and Molecular Biology, 34, 738-745. http://dx.doi.org/10.1165/rcmb.2005-0254OC.

Lozano, R., Naghavi, M., Foreman, K., Lim, S., Shibuya, K., Aboyans, V., ... Memish, Z. A. (2012). Global and regional mortality from 235 causes of death for 20 age groups in 1990 and 2010: A systematic analysis for the Global Burden of Disease Study 2010. Lancet (London, England), 380, 2095-2128. http://dx.doi.org/10.1016/S01406736(12)61728-0.

Lumsden, A. B., McLean, A., \& Lamb, D. (1984). Goblet and Clara cells of human distal airways: Evidence for smoking induced changes in their numbers. Thorax, 39, 844-849.

Lundgren, R., Söderberg, M., Hörstedt, P., \& Stenling, R. (1988). Morphological studies of bronchial mucosal biopsies from asthmatics before and after ten years of treatment with inhaled steroids. The European Respiratory Journal, 1, 883-889.

Lykkedegn, S., Sorensen, G. L., Beck-Nielsen, S. S., \& Christesen, H. T. (2015). The impact of vitamin D on fetal and neonatal lung maturation. A systematic review. American Journal of Physiology. Lung Cellular and Molecular Physiology, 308, L587-602. http:// dx.doi.org/10.1152/ajplung.00117.2014.

Ma, M.-S., Czepiel, M., Krause, T., Schäfer, K.-H., Boddeke, E., \& Copray, S. (2014). Generation of induced pluripotent stem cells from hair follicle bulge neural crest stem cells. Cellular Reprogramming, 16, 307-313. http://dx.doi.org/10.1089/cell.2014. 0018.

Maden, M., \& Hind, M. (2004). Retinoic acid in alveolar development, maintenance and regeneration. Philosophical Transactions of the Royal Society of London. Series B Biological Sciences, 359, 799-808. http://dx.doi.org/10.1098/rstb.2004.1470.

Maeda, Y., Chen, G., Xu, Y., Haitchi, H. M., Du, L., Keiser, A. R., ... Whitsett, J. A. (2011). Airway epithelial transcription factor NK2 homeobox 1 inhibits mucous cell metaplasia and Th2 inflammation. American Journal of Respiratory and Critical Care Medicine, 184, 421-429. http://dx.doi.org/10.1164/rccm.201101-01060C.

Mahmood, M. Q., Sohal, S. S., Shukla, S. D., Ward, C., Hardikar, A., Noor, W. D., .. Walters, E. H. (2015). Epithelial mesenchymal transition in smokers: Large versus small airways and relation to airflow obstruction. International Journal of Chronic Obstructive Pulmonary Disease, 10, 1515-1524. http://dx.doi.org/10.2147/COPD S81032.

Mandell, E., Seedorf, G., Gien, J., \& Abman, S. H. (2014). Vitamin D treatment improves survival and infant lung structure after intra-amniotic endotoxin exposure in rats: Potential role for the prevention of bronchopulmonary dysplasia. American Journal of Physiology. Lung Cellular and Molecular Physiology, 306, L420-428. http://dx.doi.org/ 10.1152/ajplung.00344.2013.

March, T. H., Bowen, L. E., Finch, G. L., Nikula, K. J., Wayne, B. J., \& Hobbs, C. H. (2005). Effects of strain and treatment with inhaled all-trans-retinoic acid on cigarette smokeinduced pulmonary emphysema in mice. COPD, 2, 289-302.

March, T. H., Cossey, P. Y., Esparza, D. C., Dix, K. J., McDonald, J. D., \& Bowen, L. E. (2004). Inhalation administration of all-trans-retinoic acid for treatment of elastaseinduced pulmonary emphysema in Fischer 344 rats. Experimental Lung Research, 30, 383-404. http://dx.doi.org/10.1080/01902140490463142.

Marchetto, M. C. N., Carromeu, C., Acab, A., Yu, D., Yeo, G. W., Mu, Y., ... Muotri, A. R. (2010). A model for neural development and treatment of Rett syndrome using human induced pluripotent stem cells. Cell, 143, 527-539. http://dx.doi.org/10 1016/j.cell.2010.10.016.

Martin, G. R. (1981). Isolation of a pluripotent cell line from early mouse embryos cultured in medium conditioned by teratocarcinoma stem cells. Proceedings of the National Academy of Sciences of the United States of America, 78, 7634-7638.

Martinez, F. D. (2016). Early-life origins of chronic obstructive pulmonary disease. The New England Journal of Medicine, 375, 871-878. http://dx.doi.org/10.1056/ NEJMra1603287.

Massaro, D., \& Massaro, G. D. (1986). Dexamethasone accelerates postnatal alveolar wall thinning and alters wall composition. The American Journal of Physiology, 251, R218-224.

Massaro, G. D., \& Massaro, D. (1996). Postnatal treatment with retinoic acid increases the number of pulmonary alveoli in rats. The American Journal of Physiology, 270, L305-310.

Massaro, G. D., \& Massaro, D. (2000). Retinoic acid treatment partially rescues failed septation in rats and in mice. American Journal of Physiology. Lung Cellular and Molecular Physiology, 278, L955-960.

Massaro, G. D., Massaro, D., \& Chambon, P. (2003). Retinoic acid receptor-alpha regulates pulmonary alveolus formation in mice after, but not during, perinatal period.
American Journal of Physiology. Lung Cellular and Molecular Physiology, 284, L431-433. http://dx.doi.org/10.1152/ajplung.00245.2002.

Matalon, S., \& O’Brodovich, H. (1999). Sodium channels in alveolar epithelial cells: Molecular characterization, biophysical properties, and physiological significance. Annual Review of Physiology, 61, 627-661. http://dx.doi.org/10.1146/annurev. physiol.61.1.627.

Matsuno, K., Mae, S.-I., Okada, C., Nakamura, M., Watanabe, A., Toyoda, T., ... Osafune, K. (2016). Redefining definitive endoderm subtypes by robust induction of human induced pluripotent stem cells. Differentiation: Research in Biological Diversity, 92, 281-290. http://dx.doi.org/10.1016/j.diff.2016.04.002.

Matthay, M. A., Folkesson, H. G., \& Clerici, C. (2002). Lung epithelial fluid transport and the resolution of pulmonary edema. Physiological Reviews, 82, 569-600. http://dx.doi. org/10.1152/physrev.00003.2002.

McDonough, J. E., Yuan, R., Suzuki, M., Seyednejad, N., Elliott, W. M., Sanchez, P. G., .. Hogg, J. C. (2011). Small-airway obstruction and emphysema in chronic obstructive pulmonary disease. The New England Journal of Medicine, 365, 1567-1575. http://dx. doi.org/10.1056/NEJMoa1106955.

McGeachie, M. J., Yates, K. P., Zhou, X., Guo, F., Sternberg, A. L., Van Natta, M. L., ... CAMP Research Group (2016). Patterns of growth and decline in lung function in persistent childhood asthma. The New England Journal of Medicine, 374, 1842-1852. http://dx.doi.org/10.1056/NEJMoa1513737.

McGrath-Morrow, S. A., Cho, C., Cho, C., Zhen, L., Hicklin, D. J., \& Tuder, R. M. (2005). Vascular endothelial growth factor receptor 2 blockade disrupts postnatal lung development. American Journal of Respiratory Cell and Molecular Biology, 32, 420-427. http://dx.doi.org/10.1165/rcmb.2004-02870C.

Merkert, S., \& Martin, U. (2016). Targeted genome engineering using designer nucleases: State of the art and practical guidance for application in human pluripotent stem cells. Stem Cell Research, 16, 377-386. http://dx.doi.org/10.1016/j.scr.2016.02.027.

Metzler, M. D., \& Snyder, J. M. (1993). Retinoic acid differentially regulates expression of surfactant-associated proteins in human fetal lung. Endocrinology, 133, 1990-1998. http://dx.doi.org/10.1210/endo.133.5.8404646.

Miyazaki, S., Yamamoto, H., Miyoshi, N., Takahashi, H., Suzuki, Y., Haraguchi, N., ... Mori, M. (2012). Emerging methods for preparing iPS cells. Japanese Journal of Clinical Oncology, 42, 773-779. http://dx.doi.org/10.1093/jjco/hys108.

Moheimani, F., Roth, H. M., Cross, J., Reid, A. T., Shaheen, F., Warner, S. M., ... Knight, D. A. (2015). Disruption of $\beta$-catenin/CBP signaling inhibits human airway epithelialmesenchymal transition and repair. The International Journal of Biochemistry \& Cell Biology, 68, 59-69. http://dx.doi.org/10.1016/j.biocel.2015.08.014.

von Moltke, J., Ji, M., Liang, H.-E., \& Locksley, R. M. (2016). Tuft-cell-derived IL-25 regulates an intestinal ILC2-epithelial response circuit. Nature, 529, 221-225. http:/, dx.doi.org/10.1038/nature16161.

Morales, W. J., O'Brien, W. F., Angel, J. L., Knuppel, R. A., \& Sawai, S. (1989). Fetal lung maturation: The combined use of corticosteroids and thyrotropin-releasing hormone. Obstetrics and Gynecology, 73, 111-116.

Mori, M., Mahoney, J. E., Stupnikov, M. R., Paez-Cortez, J. R., Szymaniak, A. D., Varelas, X., ... Cardoso, W. V. (2015). Notch3-Jagged signaling controls the pool of undifferentiated airway progenitors. Development (Cambridge, England), 142, 258-267. http://dx.doi.org/10.1242/dev.116855.

Mou, H., Zhao, R., Sherwood, R., Ahfeldt, T., Lapey, A., Wain, J., ... Rajagopal, J. (2012). Generation of multipotent lung and airway progenitors from mouse ESCs and patientspecific cystic fibrosis iPSCs. Cell Stem Cell, 10, 385-397. http://dx.doi.org/10.1016/ j.stem.2012.01.018.

Müllerova, H., Maselli, D. J., Locantore, N., Vestbo, J., Hurst, J. R., Wedzicha, J. A., ... Anzueto, A. (2015). Hospitalized exacerbations of COPD: Risk factors and outcomes in the ECLIPSE cohort. Chest, 147, 999-1007. http://dx.doi.org/10.1378/chest.140655.

Musunuru, K. (2013). Genome editing of human pluripotent stem cells to generate human cellular disease models. Disease Models \& Mechanisms, 6, 896-904. http://dx.doi.org/ $10.1242 / \mathrm{dmm} .012054$.

Nadkarni, R. R., Abed, S., \& Draper, J. S. (2016). Organoids as a model system for studying human lung development and disease. Biochemical and Biophysical Research Communications, 473, 675-682. http://dx.doi.org/10.1016/j.bbrc.2015.12.091.

Nelin, L. D., \& Bhandari, V. (2017). How to decrease bronchopulmonary dysplasia in your neonatal intensive care unit today and "tomorrow". F1000Research, 6, 539. http://dx. doi.org/10.12688/f1000research.10832.1.

Nowrin, K., Sohal, S. S., Peterson, G., Patel, R., \& Walters, E. H. (2014). Epithelial-mesenchymal transition as a fundamental underlying pathogenic process in COPD air ways: Fibrosis, remodeling and cancer. Expert Review of Respiratory Medicine, 8, 547-559. http://dx.doi.org/10.1586/17476348.2014.948853.

O'Brodovich, H. M. (1996). Immature epithelial $\mathrm{Na}^{+}$channel expression is one of the pathogenetic mechanisms leading to human neonatal respiratory distress syndrome. Proceedings of the Association of American Physicians, 108, 345-355.

Ochs, M., Nyengaard, J. R., Jung, A., Knudsen, L., Voigt, M., Wahlers, T., ... Gundersen, H. J. G. (2004). The number of alveoli in the human lung. American Journal of Respiratory and Critical Care Medicine, 169, 120-124. http://dx.doi.org/10.1164/ rccm.200308-11070C.

Okita, K., Nakagawa, M., Hyenjong, H., Ichisaka, T., \& Yamanaka, S. (2008). Generation of mouse induced pluripotent stem cells without viral vectors. Science, 322, 949-953. http://dx.doi.org/10.1126/science.1164270.

Oldenburger, A., Poppinga, W. J., Kos, F., de Bruin, H. G., Rijks, W. F., Heijink, I. H., ... Schmidt, M. (2014). A-kinase anchoring proteins contribute to loss of E-cadherin and bronchial epithelial barrier by cigarette smoke. American Journal of Physiology. Cell Physiology, 306, C585-597. http://dx.doi.org/10.1152/ajpcell.00183.2013.

Ordoñez, C. L., Khashayar, R., Wong, H. H., Ferrando, R., Wu, R., Hyde, D. M., ... Fahy, J. V. (2001). Mild and moderate asthma is associated with airway goblet cell hyperplasia and abnormalities in mucin gene expression. American Journal of Respiratory 
and Critical Care Medicine, 163, 517-523. http://dx.doi.org/10.1164/ajrccm.163.2 2004039.

Paisley, D., Bevan, L., Choy, K. J., \& Gross, C. (2014). The pneumonectomy model of compensatory lung growth: Insights into lung regeneration. Pharmacology \& Therapeutics, 142, 196-205. http://dx.doi.org/10.1016/j.pharmthera.2013.12.006. rdo-Saganta, A., Law, B. M., Gonzalez-Celeiro, M., Vinarsky, V., \& Rajagopal, J. (2013) Ciliated cells of pseudostratified airway epithelium do not become mucous cells after ovalbumin challenge. American Journal of Respiratory Cell and Molecular Biology, 48, 364-373. http://dx.doi.org/10.1165/rcmb.2012-01460C.

Park, K.-S., Korfhagen, T. R., Bruno, M. D., Kitzmiller, J. A., Wan, H., Wert, S. E., .. Whitsett, J. A. (2007). SPDEF regulates goblet cell hyperplasia in the airway epithelium. The Journal of Clinical Investigation, 117, 978-988. http://dx.doi.org/10. 1172/JCI29176.

Park, H.-S., Park, J.-W., Kim, H.-J., Choi, C. W., Lee, H.-J., Kim, B. I., \& Chun, Y.-S. (2013). Sildenafil alleviates bronchopulmonary dysplasia in neonatal rats by activating the hypoxia-inducible factor signaling pathway. American Journal of Respiratory Cell and Molecular Biology, 48, 105-113. http://dx.doi.org/10.1165/rcmb. 2012-00430C.

Pascoe, S., Locantore, N., Dransfield, M. T., Barnes, N. C., \& Pavord, I. D. (2015). Blood eosinophil counts, exacerbations, and response to the addition of inhaled fluticasone furoate to vilanterol in patients with chronic obstructive pulmonary disease: A secondary analysis of data from two parallel randomised controlled trials. The Lancet Respiratory Medicine, 3, 435-442. http://dx.doi.org/10.1016/S2213-2600(15) 00106-X.

Peng, T., \& Morrisey, E. E. (2013). Development of the pulmonary vasculature: Current understanding and concepts for the future. Pulmonary Circulation, 3, 176-178. http:// dx.doi.org/10.4103/2045-8932.109954.

Pera, M. F. (2011). Stem cells: The dark side of induced pluripotency. Nature, 471, 46-47. http://dx.doi.org/10.1038/471046a.

Perez, K. M., \& Laughon, M. (2015). Sildenafil in term and premature infants: A systematic review. Clinical Therapeutics, 37, 2598-2607.e1. http://dx.doi.org/10.1016/j clinthera. 2015.07.019.

Perl, A.-K. T., Riethmacher, D., \& Whitsett, J. A. (2011). Conditional depletion of airway progenitor cells induces peribronchiolar fibrosis. American Journal of Respiratory and Critical Care Medicine, 183, 511-521. http://dx.doi.org/10.1164/recm.2010050744OC.

Perotin, J.-M., Adam, D., Vella-Boucaud, J., Delepine, G., Sandu, S., Jonvel, A.-C., . Deslee, G. (2014). Delay of airway epithelial wound repair in COPD is associated with airflow obstruction severity. Respiratory Research, 15, 151. http://dx.doi.org/10. 1186/s12931-014-0151-9.

Peters, E. J., Morice, R., Benner, S. E., Lippman, S., Lukeman, J., Lee, J. S., ... Hong, W. K. (1993). Squamous metaplasia of the bronchial mucosa and its relationship to smoking. Chest, 103, 1429-1432.

Pezzulo, A. A., Starner, T. D., Scheetz, T. E., Traver, G. L., Tilley, A. E., Harvey, B.-G., .. Zabner, J. (2011). The air-liquid interface and use of primary cell cultures are important to recapitulate the transcriptional profile of in vivo airway epithelia. American Journal of Physiology. Lung Cellular and Molecular Physiology, 300, L25-31. http://dx.doi.org/10.1152/ajplung.00256.2010.

Pillai, S. G., Ge, D., Zhu, G., Kong, X., Shianna, K. V., Need, A. C., ... Investigators, I. C. G. N. (2009). A genome-wide association study in chronic obstructive pulmonary disease (COPD): Identification of two major susceptibility loci. PLOS Genetics, 5, e1000421. http://dx.doi.org/10.1371/journal.pgen.1000421.

van der Plaat, D. A., de Jong, K., Lahousse, L., Faiz, A., Vonk, J. M., van Diemen, C. C., ... Boezen, H. M. (2016). Genome-wide association study on the FEV1/FVC ratio in never-smokers identifies HHIP and FAM13A. The Journal of Allergy and Clinical Immunology. http://dx.doi.org/10.1016/j.jaci.2016.06.062.

Polosa, R., Puddicombe, S. M., Krishna, M. T., Tuck, A. B., Howarth, P. H., Holgate, S. T. \& Davies, D. E. (2002). Expression of c-erbB receptors and ligands in the bronchial epithelium of asthmatic subjects. The Journal of Allergy and Clinical Immunology, 109, 75-81.

Puchelle, E., Zahm, J.-M., Tournier, J.-M., \& Coraux, C. (2006). Airway epithelial repair, regeneration, and remodeling after injury in chronic obstructive pulmonary disease. Proceedings of the American Thoracic Society, 3, 726-733. http://dx.doi.org/10.1513/ pats.200605-126SF.

Puddicombe, S. M., Polosa, R., Richter, A., Krishna, M. T., Howarth, P. H., Holgate, S. T. \& Davies, D. E. (2000). Involvement of the epidermal growth factor receptor in epithelial repair in asthma. The FASEB Journal: Official Publication of the Federation of American Societies for Experimental Biology, 14, 1362-1374.

Rajendrasozhan, S., Yang, S.-R., Kinnula, V. L., \& Rahman, I. (2008). SIRT1, an antiin flammatory and antiaging protein, is decreased in lungs of patients with chronic obstructive pulmonary disease. American Journal of Respiratory and Critical Care Medicine, 177, 861-870. http://dx.doi.org/10.1164/rccm.200708-12690C.

Ramirez-Icaza, G., Mohammed, K. A., Nasreen, N., Van Horn, R. D., Hardwick, J. A., Sanders, K. L., ... Antony, V. B. (2004). Th2 cytokines IL-4 and IL-13 downregulate paxillin expression in bronchial airway epithelial cells. Journal of Clinical Immunology, 24, 426-434. http://dx.doi.org/10.1023/B:JOCI.0000029111.27168.c6.

Randell, S. H. (2006). Airway epithelial stem cells and the pathophysiology of chronic obstructive pulmonary disease. Proceedings of the American Thoracic Society, 3, 718-725. http://dx.doi.org/10.1513/pats.200605-117SF.

Rankin, J. A., Picarella, D. E., Geba, G. P., Temann, U. A., Prasad, B., DiCosmo, B., Flavell, R. A. (1996). Phenotypic and physiologic characterization of transgenic mice expressing interleukin 4 in the lung: Lymphocytic and eosinophilic inflammation without airway hyperreactivity. Proceedings of the National Academy of Sciences of the United States of America, 93, 7821-7825.

Rawlins, E. L., Okubo, T., Xue, Y., Brass, D. M., Auten, R. L., Hasegawa, H., ... Hogan, B. L. M. (2009). The role of Scgblal + Clara cells in the long-term maintenance and repair of lung airway, but not alveolar, epithelium. Cell Stem Cell, 4, 525-534. http://dx.doi. org/10.1016/j.stem.2009.04.002.

Reddel, H. K., Bateman, E. D., Becker, A., Boulet, L.-P., Cruz, A. A., Drazen, J. M., .. FitzGerald, J. M. (2015). A summary of the new GINA strategy: A roadmap to asthma control. The European Respiratory Journal, 46, 622-639. http://dx.doi.org/10.1183/ 13993003.00853-2015.

Robbins, S. T., \& Fletcher, A. B. (1993). Early vs delayed vitamin A supplementation in very-low-birth-weight infants. JPEN Journal of Parenteral and Enteral Nutrition, 17, 220-225.

Roberts, D., Brown, J., Medley, N., \& Dalziel, S. R. (2017). Antenatal corticosteroids for accelerating fetal lung maturation for women at risk of preterm birth. Cochrane Database of Systematic Reviews, 3, CD004454. http://dx.doi.org/10.1002/14651858. CD004454.pub3.

Roberts, D., \& Dalziel, S. (2006). Antenatal corticosteroids for accelerating fetal lung maturation for women at risk of preterm birth. Cochrane Database of Systematic ReviewsCD004454. http://dx.doi.org/10.1002/14651858.CD004454.pub2.

Rock, J. R., Gao, X., Xue, Y., Randell, S. H., Kong, Y.-Y., \& Hogan, B. L. M. (2011). Notchdependent differentiation of adult airway basal stem cells. Cell Stem Cell, 8, 639-648. http://dx.doi.org/10.1016/j.stem.2011.04.003.

Rock, J. R., Onaitis, M. W., Rawlins, E. L., Lu, Y., Clark, C. P., Xue, Y., ... Hogan, B. L. M. (2009). Basal cells as stem cells of the mouse trachea and human airway epithelium. Proceedings of the National Academy of Sciences of the United States of America, 106, 12771-12775. http://dx.doi.org/10.1073/pnas.0906850106.

Rooney, S. A., Gobran, L., Gross, I., Wai-lee, T. S., Nardone, L. L., \& Motoyama, E. K. (1976). Studies on pulmonary surfactant. Effects of cortisol administration to fetal rabbits on lung phospholipid content, composition and biosynthesis. Biochimica et Biophysica Acta, 450, 121-130.

Rosen, C., Shezen, E., Aronovich, A., Klionsky, Y. Z., Yaakov, Y., Assayag, M., ... Reisner, Y. (2015). Preconditioning allows engraftment of mouse and human embryonic lung cells, enabling lung repair in mice. Nature Medicine, 21, 869-879. http://dx.doi.org/ $10.1038 / \mathrm{nm} .3889$.

Ross, A. J., Dailey, L. A., Brighton, L. E., \& Devlin, R. B. (2007). Transcriptional profiling of mucociliary differentiation in human airway epithelial cells. American Journal of Respiratory Cell and Molecular Biology, 37, 169-185. http://dx.doi.org/10.1165/rcmb. 2006-04660C.

Roth, M. D., Connett, J. E., D’Armiento, J. M., Foronjy, R. F., Friedman, P. J., Goldin, J. G., ... FORTE Study Investigators (2006). Feasibility of retinoids for the treatment of emphysema study. Chest, 130, 1334-1345. http://dx.doi.org/10.1378/chest.130.5. 1334.

Rouhani, F., Kumasaka, N., de Brito, M. C., Bradley, A., Vallier, L., \& Gaffney, D. (2014). Genetic background drives transcriptional variation in human induced pluripotent stem cells. PLoS Genetics, 10, e1004432. http://dx.doi.org/10.1371/journal.pgen. 1004432.

Rush, M. G., Ul-Haq, R., \& Chytil, F. (1991). Opposing effects of retinoic acid and dexamethasone on cellular retinol-binding protein ribonucleic acid levels in the rat. Endocrinology, 129, 705-709. http://dx.doi.org/10.1210/endo-129-2-705.

Ryter, S. W., Lee, S.-J., \& Choi, A. M. (2010). Autophagy in cigarette smoke-induced chronic obstructive pulmonary disease. Expert Review of Respiratory Medicine, 4, 573-584. http://dx.doi.org/10.1586/ers.10.61.

Saetta, M., Turato, G., Baraldo, S., Zanin, A., Braccioni, F., Mapp, C. E., ... Fabbri, L. M. (2000). Goblet cell hyperplasia and epithelial inflammation in peripheral airways of smokers with both symptoms of chronic bronchitis and chronic airflow limitation. American Journal of Respiratory and Critical Care Medicine, 161, 1016-1021. http://dx. doi.org/10.1164/ajrccm.161.3.9907080.

Savale, L., Chaouat, A., Bastuji-Garin, S., Marcos, E., Boyer, L., Maitre, B., ... Adnot, S. (2009). Shortened telomeres in circulating leukocytes of patients with chronic obstructive pulmonary disease. American Journal of Respiratory and Critical Care Medicine, 179, 566-571. http://dx.doi.org/10.1164/rccm.200809-13980C.

Schaefer, C. (2003). Angiotensin II-receptor-antagonists: Further evidence of fetotoxicity but not teratogenicity. Birth Defects Research, Part A: Clinical and Molecular Teratology, 67, 591-594. http://dx.doi.org/10.1002/bdra.10081.

Schmidt, B., Roberts, R. S., Davis, P., Doyle, L. W., Barrington, K. J., Ohlsson, A., Caffeine for Apnea of Prematurity Trial Group (2006). Caffeine therapy for apnea of prematurity. The New England Journal of Medicine, 354, 2112-2121. http://dx.doi. org/10.1056/NEJMoa054065.

Seki, T., Yuasa, S., Oda, M., Egashira, T., Yae, K., Kusumoto, D., ... Fukuda, K. (2010). Generation of induced pluripotent stem cells from human terminally differentiated circulating T cells. Cell Stem Cell, 7, 11-14. http://dx.doi.org/10.1016/j.stem.2010 06.003.

Selman, M., Pardo, A., \& Kaminski, N. (2008). Idiopathic pulmonary fibrosis: Aberrant recapitulation of developmental programs? PLoS Medicine, 5, e62. http://dx.doi.org/ 10.1371/journal.pmed.0050062.

Service, R. F. (2012). Bioengineering. Lung-on-a-chip breathes new life into drug dis covery. Science, 338, 731. http://dx.doi.org/10.1126/science.338.6108.731.

Sharma, S., Tantisira, K., Carey, V., Murphy, A. J., Lasky-Su, J., Celedón, J. C., ... Weiss, S. T. (2010). A role for Wnt signaling genes in the pathogenesis of impaired lung function in asthma. American Journal of Respiratory and Critical Care Medicine, 181 328-336. http://dx.doi.org/10.1164/rccm.200907-10090C.

Shaykhiev, R., \& Crystal, R. G. (2014). Early events in the pathogenesis of chronic obstructive pulmonary disease. Smoking-induced reprogramming of airway epithelial basal progenitor cells. Annals of the American Thoracic Society, 11, S252-S258. http:// dx.doi.org/10.1513/AnnalsATS.201402-049AW.

Shaykhiev, R., Otaki, F., Bonsu, P., Dang, D. T., Teater, M., Strulovici-Barel, Y., ... Crystal, R. G. (2011). Cigarette smoking reprograms apical junctional complex molecular architecture in the human airway epithelium in vivo. Cellular and Molecular Life Sciences: CMLS, 68, 877-892. http://dx.doi.org/10.1007/s00018-010-0500-x. 
Shaykhiev, R., Zuo, W.-L., Chao, I., Fukui, T., Witover, B., Brekman, A., \& Crystal, R. G. (2013). EGF shifts human airway basal cell fate toward a smoking-associated airway epithelial phenotype. Proceedings of the National Academy of Sciences of the United States of America, 110, 12102-12107. http://dx.doi.org/10.1073/pnas.1303058110. Shi, W., Chen, F., \& Cardoso, W. V. (2009). Mechanisms of lung development: Contribution to adult lung disease and relevance to chronic obstructive pulmonary disease. Proceedings of the American Thoracic Society, 6, 558-563. http://dx.doi.org/ 10.1513/pats.200905-031RM.

Shinwell, E. S., Portnov, I., Meerpohl, J. J., Karen, T., \& Bassler, D. (2016). Inhaled corticosteroids for bronchopulmonary dysplasia: A meta-analysis. Pediatrics, 138. http://dx.doi.org/10.1542/peds.2016-2511.

Shu, W., Guttentag, S., Wang, Z., Andl, T., Ballard, P., Lu, M. M., ... Morrisey, E. E. (2005) Wnt/beta-catenin signaling acts upstream of N-myc, BMP4, and FGF signaling to regulate proximal-distal patterning in the lung. Developmental Biology, 283, 226-239. http://dx.doi.org/10.1016/j.ydbio.2005.04.014.

Smiley, S. T., Stitt, T. N., \& Grusby, M. J. (1997). Cross-linking of protein S bound to lymphocytes promotes aggregation and inhibits proliferation. Cellular Immunology, 181, 120-126. http://dx.doi.org/10.1006/cimm.1997.1210.

Snoeck, H.-W. (2015). Modeling human lung development and disease using pluripotent stem cells. Development (Cambridge, England), 142, 13-16. http://dx.doi.org/10. 1242/dev.115469.

Sohal, S. S., Mahmood, M. Q., \& Walters, E. H. (2014). Clinical significance of epithelial mesenchymal transition (EMT) in chronic obstructive pulmonary disease (COPD): Potential target for prevention of airway fibrosis and lung cancer. Clinical and Translational Medicine, 3, 33. http://dx.doi.org/10.1186/s40169-014-0033-2.

Sohal, S. S., Reid, D., Soltani, A., Ward, C., Weston, S., Muller, H. K., ... Walters, E. H. (2010). Reticular basement membrane fragmentation and potential epithelial mesenchymal transition is exaggerated in the airways of smokers with chronic obstructive pulmonary disease. Respirology (Carlton, Vic.), 15, 930-938. http://dx.doi. org/10.1111/j.1440-1843.2010.01808.x.

Sohal, S. S., Reid, D., Soltani, A., Ward, C., Weston, S., Muller, H. K., ... Walters, E. H. (2011). Evaluation of epithelial mesenchymal transition in patients with chronic obstructive pulmonary disease. Respiratory Research, 12, 130. http://dx.doi.org/10. 1186/1465-9921-12-130.

Sohal, S. S., \& Walters, E. H. (2013). Role of epithelial mesenchymal transition (EMT) in chronic obstructive pulmonary disease (COPD). Respiratory Research, 14, 120. http:// dx.doi.org/10.1186/1465-9921-14-120.

Sohal, S. S., Ward, C., \& Walters, E. H. (2014). Importance of epithelial mesenchymal transition (EMT) in COPD and asthma. Thorax, 69, 768. http://dx.doi.org/10.1136/ thoraxjnl-2014-205582.

Soll, R. F. (2012). Inhaled nitric oxide for respiratory failure in preterm infants. Neonatology, 102, 251-253. http://dx.doi.org/10.1159/000338552.

Somborac-Bacura, A., van der Toorn, M., Franciosi, L., Slebos, D.-J., Zanic-Grubisic, T., Bischoff, R., \& van Oosterhout, A. J. M. (2013). Cigarette smoke induces endoplasmic reticulum stress response and proteasomal dysfunction in human alveolar epithelial cells. Experimental Physiology, 98, 316-325. http://dx.doi.org/10.1113/expphysiol. 2012.067249 .

Spanjer, A. I. R., Baarsma, H. A., Oostenbrink, L. M., Jansen, S. R., Kuipers, C. C., Lindner, M., ... Königshoff, M. (2016). TGF- $\beta$-induced profibrotic signaling is regulated in part by the WNT receptor Frizzled-8. The FASEB Journal: Official Publication of the Federation of American Societies for Experimental Biology, 30, 1823-1835. http://dx. doi.org/10.1096/fj.201500129.

Spanjer, A. I. R., Menzen, M. H., Dijkstra, A. E., van den Berge, M., Boezen, H. M., Nickle, D. C., ... Gosens, R. (2016). A pro-inflammatory role for the Frizzled-8 receptor in chronic bronchitis. Thorax, 71, 312-322. http://dx.doi.org/10.1136/thoraxjnl-2015206958.

Stănescu, D., Sanna, A., Veriter, C., \& Robert, A. (1998). Identification of smokers susceptible to development of chronic airflow limitation: A 13-year follow-up. Chest, 114, 416-425.

Staudt, M. R., Buro-Auriemma, L. J., Walters, M. S., Salit, J., Vincent, T., Shaykhiev, R., .. Crystal, R. G. (2014). Airway basal stem/progenitor cells have diminished capacity to regenerate airway epithelium in chronic obstructive pulmonary disease. American Journal of Respiratory and Critical Care Medicine, 190, 955-958. http://dx.doi.org/10. 1164/rccm.201406-1167LE.

Stevens, P. T., Kicic, A., Sutanto, E. N., Knight, D. A., \& Stick, S. M. (2008). Dysregulated repair in asthmatic paediatric airway epithelial cells: The role of plasminogen activator inhibitor-1. Clinical \& Experimental Allergy: Journal of the British Society for Allergy \& Clinical Immunology, 38, 1901-1910. http://dx.doi.org/10.1111/j.13652222.2008.03093.x.

Stoscheck, C. M., Nanney, L. B., \& King, L. E. (1992). Quantitative determination of EGF-R during epidermal wound healing. The Journal of Investigative Dermatology, 99, 645-649.

Su, R. J., Neises, A., \& Zhang, X.-B. (2016). Generation of iPS cells from human peripheral blood mononuclear cells using episomal vectors. Methods in Molecular Biology (Clifton, N.J.), 1357, 57-69. http://dx.doi.org/10.1007/7651_2014_139.

Sutherland, E. R., \& Martin, R. J. (2003). Airway inflammation in chronic obstructive pulmonary disease: Comparisons with asthma. The Journal of Allergy and Clinical Immunology, 112, 819-827. quiz 828 https://doi.org/10.1016/S0091.

Takahashi, K., Tanabe, K., Ohnuki, M., Narita, M., Ichisaka, T., Tomoda, K., \& Yamanaka, S. (2007). Induction of pluripotent stem cells from adult human fibroblasts by defined factors. Cell, 131, 861-872. http://dx.doi.org/10.1016/j.cell.2007.11.019.

Takahashi, K., \& Yamanaka, S. (2006). Induction of pluripotent stem cells from mouse embryonic and adult fibroblast cultures by defined factors. Cell, 126, 663-676. http://dx.doi.org/10.1016/j.cell.2006.07.024.

Takeyama, K., Fahy, J. V., \& Nadel, J. A. (2001). Relationship of epidermal growth factor receptors to goblet cell production in human bronchi. American Journal of Respiratory and Critical Care Medicine, 163, 511-516. http://dx.doi.org/10.1164/ajrccm.163.2. 2001038.

Tang, J.-R., Markham, N. E., Lin, Y.-J., McMurtry, I. F., Maxey, A., Kinsella, J. P., \& Abman, S. H. (2004). Inhaled nitric oxide attenuates pulmonary hypertension and improves lung growth in infant rats after neonatal treatment with a VEGF receptor inhibitor. American Journal of Physiology. Lung Cellular and Molecular Physiology, 287, L344-351. http://dx.doi.org/10.1152/ajplung.00291.2003.

Tata, P. R., Mou, H., Pardo-Saganta, A., Zhao, R., Prabhu, M., Law, B. M., ... Rajagopal, J. (2013). Dedifferentiation of committed epithelial cells into stem cells in vivo. Nature, 503, 218-223. http://dx.doi.org/10.1038/nature12777.

Thébaud, B., \& Abman, S. H. (2007). Bronchopulmonary dysplasia: Where have all the vessels gone? Roles of angiogenic growth factors in chronic lung disease. American Journal of Respiratory and Critical Care Medicine, 175, 978-985. http://dx.doi.org/10. 1164/rccm.200611-1660PP.

Thébaud, B., Ladha, F., Michelakis, E. D., Sawicka, M., Thurston, G., Eaton, F., ... Archer, S. L. (2005). Vascular endothelial growth factor gene therapy increases survival, promotes lung angiogenesis, and prevents alveolar damage in hyperoxia-induced lung injury: Evidence that angiogenesis participates in alveolarization. Circulation, 112, 2477-2486. http://dx.doi.org/10.1161/CIRCULATIONAHA.105.541524.

Thomson, J. A., Itskovitz-Eldor, J., Shapiro, S. S., Waknitz, M. A., Swiergiel, J. J., Marshall, V. S., \& Jones, J. M. (1998). Embryonic stem cell lines derived from human blastocysts. Science, 282, 1145-1147.

Tilley, A. E., Harvey, B.-G., Heguy, A., Hackett, N. R., Wang, R., O’Connor, T. P., \& Crystal, R. G. (2009). Down-regulation of the notch pathway in human airway epithelium in association with smoking and chronic obstructive pulmonary disease. American Journal of Respiratory and Critical Care Medicine, 179, 457-466. http://dx. doi.org/10.1164/rccm.200705-7950C.

Tsao, P.-N., Wei, S.-C., Wu, M.-F., Huang, M.-T., Lin, H.-Y., Lee, M.-C., ... Cardoso, W. V. (2011). Notch signaling prevents mucous metaplasia in mouse conducting airways during postnatal development. Development (Cambridge, England), 138, 3533-3543. http://dx.doi.org/10.1242/dev.063727.

Tschanz, S. A., Makanya, A. N., Haenni, B., \& Burri, P. H. (2003). Effects of neonatal highdose short-term glucocorticoid treatment on the lung: A morphologic and morphometric study in the rat. Pediatric Research, 53, 72-80. http://dx.doi.org/10.1203/ 00006450-200301000-00014.

Tsuji, T., Aoshiba, K., \& Nagai, A. (2006). Alveolar cell senescence in patients with pulmonary emphysema. American Journal of Respiratory and Critical Care Medicine, 174, 886-893. http://dx.doi.org/10.1164/rccm.200509-13740C.

Turner, J., Roger, J., Fitau, J., Combe, D., Giddings, J., Heeke, G. V., \& Jones, C. E. (2011). Goblet cells are derived from a FOXJ1-expressing progenitor in a human airway epithelium. American Journal of Respiratory Cell and Molecular Biology, 44, 276-284. http://dx.doi.org/10.1165/rcmb.2009-03040C.

Uhl, F. E., Vierkotten, S., Wagner, D. E., Burgstaller, G., Costa, R., Koch, I., ... Königshoff, M. (2015). Preclinical validation and imaging of Wnt-induced repair in human 3D lung tissue cultures. The European Respiratory Journal, 46, 1150-1166. http://dx.doi. org/10.1183/09031936.00183214.

Vallier, L. (2015). Putting induced pluripotent stem cells to the test. Nature Biotechnology, 33, 1145-1146. http://dx.doi.org/10.1038/nbt.3401.

Varas, F., Stadtfeld, M., de Andres-Aguayo, L., Maherali, N., di Tullio, A., Pantano, L., ... Graf, T. (2009). Fibroblast-derived induced pluripotent stem cells show no common retroviral vector insertions. Stem Cells (Dayton, Ohio), 27, 300-306. http://dx.doi. org/10.1634/stemcells.2008-0696.

Venkatesh, V. C., \& Katzberg, H. D. (1997). Glucocorticoid regulation of epithelial sodium channel genes in human fetal lung. The American Journal of Physiology, 273, L227-233.

Verbeken, E. K., Cauberghs, M., Mertens, I., Clement, J., Lauweryns, J. M., \& Van de Woestijne, K. P. (1992). The senile lung. Comparison with normal and emphysematous lungs. 1. Structural aspects. Chest, 101, 793-799.

Vestbo, J., Edwards, L. D., Scanlon, P. D., Yates, J. C., Agusti, A., Bakke, P., ... ECLIPSE Investigators (2011). Changes in forced expiratory volume in 1 second over time in COPD. The New England Journal of Medicine, 365, 1184-1192. http://dx.doi.org/10. 1056/NEJMoa1105482.

Voelkel, N. F., Vandivier, R. W., \& Tuder, R. M. (2006). Vascular endothelial growth factor in the lung. American Journal of Physiology. Lung Cellular and Molecular Physiology, 290, L209-221. http://dx.doi.org/10.1152/ajplung.00185.2005.

Vogelmeier, C. F., Criner, G. J., Martinez, F. J., Anzueto, A., Barnes, P. J., Bourbeau, J., Agusti, A. (2017). Global strategy for the diagnosis, management, and prevention of chronic obstructive lung disease 2017 report: GOLD executive summary. The European Respiratory Journal, 49. http://dx.doi.org/10.1183/13993003.00214-2017.

Vucic, E. A., Chari, R., Thu, K. L., Wilson, I. M., Cotton, A. M., Kennett, J. Y., ... Lam, W. L. (2014). DNA methylation is globally disrupted and associated with expression changes in chronic obstructive pulmonary disease small airways. American Journal of Respiratory Cell and Molecular Biology, 50, 912-922. http://dx.doi.org/10.1165/rcmb. 2013-03040C.

Wan, H., Kaestner, K. H., Ang, S.-L., Ikegami, M., Finkelman, F. D., Stahlman, M. T., ... Whitsett, J. A. (2004). Foxa2 regulates alveolarization and goblet cell hyperplasia. Development (Cambridge, England), 131, 953-964. http://dx.doi.org/10.1242/dev. 00966.

Wang, Q., Wang, Y., Zhang, Y., Zhang, Y., \& Xiao, W. (2013). The role of uPAR in epithelial-mesenchymal transition in small airway epithelium of patients with chronic obstructive pulmonary disease. Respiratory Research, 14, 67. http://dx.doi.org/10. 1186/1465-9921-14-67.

Warburton, D., Bellusci, S., Del Moral, P.-M., Kaartinen, V., Lee, M., Tefft, D., \& Shi, W. (2003). Growth factor signaling in lung morphogenetic centers: Automaticity, stereotypy and symmetry. Respiratory Research, 4, 5. http://dx.doi.org/10.1186/1465 9921-4-5. 
Wilk, J. B., Chen, T.-H., Gottlieb, D. J., Walter, R. E., Nagle, M. W., Brandler, B. J., .. O'Connor, G. T. (2009). A genome-wide association study of pulmonary function measures in the Framingham Heart Study. PLoS Genetics, 5, e1000429. http://dx.doi. org/10.1371/journal.pgen.1000429.

Wong, A. P., Bear, C. E., Chin, S., Pasceri, P., Thompson, T. O., Huan, L.-J., ... Rossant, J. (2012). Directed differentiation of human pluripotent stem cells into mature airway epithelia expressing functional CFTR protein. Nature Biotechnology, 30, 876-882. http://dx.doi.org/10.1038/nbt.2328.

Wong, A. P., Chin, S., Xia, S., Garner, J., Bear, C. E., \& Rossant, J. (2015). Efficient generation of functional CFTR-expressing airway epithelial cells from human pluripotent stem cells. Nature Protocols, 10, 363-381. http://dx.doi.org/10.1038/nprot. 2015.021.

Wong, A. P., Keating, A., Lu, W.-Y., Duchesneau, P., Wang, X., Sacher, A., ... Waddell, T. K. (2009). Identification of a bone marrow-derived epithelial-like population capable of repopulating injured mouse airway epithelium. The Journal of Clinical Investigation, 119, 336-348. http://dx.doi.org/10.1172/JCI36882.

Woodruff, P. G., Wolff, M., Hohlfeld, J. M., Krug, N., Dransfield, M. T., Sutherland, E. R., ... Fahy, J. V. (2010). Safety and efficacy of an inhaled epidermal growth factor receptor inhibitor (BIBW 2948 BS) in chronic obstructive pulmonary disease. American Journal of Respiratory and Critical Care Medicine, 181, 438-445. http://dx.doi.org/10. 1164/rccm.200909-14150C.

Wright, J. L., Cosio, M., \& Churg, A. (2008). Animal models of chronic obstructive pulmonary disease. American Journal of Physiology. Lung Cellular and Molecular Physiology, 295, L1-15. http://dx.doi.org/10.1152/ajplung.90200.2008.

Xiao, C., Puddicombe, S. M., Field, S., Haywood, J., Broughton-Head, V., Puxeddu, I., ... Davies, D. E. (2011). Defective epithelial barrier function in asthma. Journal of Allergy and Clinical Immunology, 128, 549-556.e1-12. http://dx.doi.org/10.1016/j.jaci.2011. 05.038 .

Xu, K., Moghal, N., \& Egan, S. E. (2012). Notch signaling in lung development and disease. Adv. Exp. Med. Biol. 727, 89-98. http://dx.doi.org/10.1007/978-1-4614-08994 . 7 .
Yamanaka, S. (2012). Induced pluripotent stem cells: Past, present, and future. Cell Stem Cell, 10, 678-684. http://dx.doi.org/10.1016/j.stem.2012.05.005.

Yeh, T. F., Chen, C. M., Wu, S. Y., Husan, Z., Li, T. C., Hsieh, W. S., ... Lin, H. C. (2016). Intratracheal administration of budesonide/surfactant to prevent bronchopulmonary dysplasia. American Journal of Respiratory and Critical Care Medicine, 193, 86-95. http://dx.doi.org/10.1164/rccm.201505-08610C.

Yu, J., Hu, K., Smuga-Otto, K., Tian, S., Stewart, R., Slukvin, I. I., \& Thomson, J. A. (2009). Human induced pluripotent stem cells free of vector and transgene sequences. Science, 324, 797-801. http://dx.doi.org/10.1126/science.1172482.

Yu, J., Vodyanik, M. A., Smuga-Otto, K., Antosiewicz-Bourget, J., Frane, J. L., Tian, S., ... Thomson, J. A. (2007). Induced pluripotent stem cell lines derived from human somatic cells. Science, 318, 1917-1920. http://dx.doi.org/10.1126/science.1151526.

Zhang, Y., Goss, A. M., Cohen, E. D., Kadzik, R., Lepore, J. J., Muthukumaraswamy, K., ... Morrisey, E. E. (2008). A Gata6-Wnt pathway required for epithelial stem cell development and airway regeneration. Nature Genetics, 40, 862-870. http://dx.doi.org/ 10.1038/ng.157.

Zhang, M., Zhang, Z., Pan, H.-Y., Wang, D.-X., Deng, Z.-T., \& Ye, X.-L. (2009). TGF-beta1 induces human bronchial epithelial cell-to-mesenchymal transition in vitro. Lung, 187, 187-194. http://dx.doi.org/10.1007/s00408-009-9139-5.

Zhao, Y., Zhao, T., Guan, J., Zhang, X., Fu, Y., Ye, J., ... Deng, H. (2015). A XEN-like state bridges somatic cells to pluripotency during chemical reprogramming. Cell, 163, 1678-1691. http://dx.doi.org/10.1016/j.cell.2015.11.017.

Zhou, X., Baron, R. M., Hardin, M., Cho, M. H., Zielinski, J., Hawrylkiewicz, I., ... Silverman, E. K. (2012). Identification of a chronic obstructive pulmonary disease genetic determinant that regulates HHIP. Human Molecular Genetics, 21, 1325-1335. http://dx.doi.org/10.1093/hmg/ddr569.

Zou, W., Zou, Y., Zhao, Z., Li, B., \& Ran, P. (2013). Nicotine-induced epithelial-mesenchymal transition via Wnt/ $\beta$-catenin signaling in human airway epithelial cells. American Journal of Physiology. Lung Cellular and Molecular Physiology, 304, L199-209. http://dx.doi.org/10.1152/ajplung.00094.2012. 